\title{
Interaction between Surface Water and Groundwater in Yinchuan Plain
}

\author{
Zizhao Cai ${ }^{1,2}$, Wenke Wang ${ }^{1, *}$, Ming Zhao ${ }^{1}$, Zhitong Ma ${ }^{1}$, Chuan $\mathrm{Lu}^{2}$ and $\mathrm{Ying} \mathrm{Li}^{3}$ \\ 1 School of Water and Environment, Chang'an University, Anta Road 126, Xi'an 710054, China; \\ caizizhao@mail.cgs.gov.cn (Z.C.); zm19920301@163.com (M.Z.); zhitongma94@163.com (Z.M.) \\ 2 Institute of Hydrogeology and Environmental Geology, Shijiazhuang 050061, China; luchuancn@163.com \\ 3 Institute of Hydrogeology and Environmental Geology of Ningxia, Yinchuan 750011, China; \\ ytly1989@gmail.com \\ * Correspondence: wenkew@chd.edu.cn; Tel.: +86-29-8233-9291
}

Received: 25 July 2020; Accepted: 15 September 2020; Published: 21 September 2020

check for updates

\begin{abstract}
The interaction of surface water (SW) and groundwater (GW) is becoming more and more complex under the effects of climate change and human activity. It is of great significance to fully understand the characteristics of regional SW-GW circulation to reveal the water circulation system and the effect of its evolution mechanism to improve the rational allocation of water resources, especially in arid and semi-arid areas. In this paper, Yinchuan Plain is selected as the study area, where the SW-GW interaction is intensive. Three typical profiles are selected to build two-dimensional hydrogeological structure models, using an integrated approach involving field investigation, numerical simulation, hydrogeochemistry and isotope analysis. The SW-GW transformation characteristics are analyzed with these models, showing that geological structure controls the SW-GW interaction in Yinchuan Plain. The SW-GW flow system presents a multi-level nested system including local, intermediate and regional flow systems. The runoff intensity and renewal rate of different flow systems are evidently different, motivating evolution of the hydro-chemical field; human activities (well mining, agricultural irrigation, ditch drainage, etc.) change the local water flow system with a certain impacting width and depth, resulting in a variation of the hydrological and hydro-chemical fields. This study presents the efficacy of an integrated approach combining numerical simulation, hydrogeochemistry and isotope data, as well as an analysis for the determination of GW-SW interactions in Yinchuan Plain.
\end{abstract}

Keywords: surface-groundwater interaction; hydrological circulation system; geological structure; human activity; arid area

\section{Introduction}

The SW-GW interaction is an important component of the water cycle in a watershed. The water balance and material exchange sustain basic functions of the SW-GW ecosystem, which in turn affect the management of water resources and ecological system protection in arid areas [1-3]. Clearly, the SW-GW interaction is controlled by topography, geology, landform conditions, climate condition and human activities, as the dynamic mechanism and ecological effect of this interaction in arid regions is very complex.

Wang et al. [4] analyzed the typical modes, hydrodynamic process and ecological impacts exerted by interactions between the river and GW in the Junggar Basin, and they concluded that the river-groundwater transformation could be controlled by geological and lithological structures. The heterogeneity of aquifers and riverbeds, hydraulic gradients, locations and structures of rivers, etc. determine the amount, direction and spatial distribution of SW-GW exchanges [5,6]. In addition, a lot of recent studies have addressed the impact of climate change and human activities on GW 
circulation and related region-wide environmental issues. The impact of human activities on the water resource system is more obvious in arid and semi-arid areas, such as in river diversion by damming [7] water diversion irrigation [8], GW overdraft [9] and water quality deterioration [10], which change the original SW-GW interaction mode and decrease their exchange in some basins. Saha et al. [11] studied the dynamics of SW-GW interactions under the impact of climate change based on the temporal average contribution of GW to SW. Their results show that these contributions vary monthly, seasonally and annually due to precipitation variations. Based on long-term observation data, Wang et al. [12] deduced the strong impacts of climate change and human activities on the GW system and basin base flow. Results indicate that the interaction between GW and SW is not only controlled by natural factors, but also affected by climate and human activities [13].

Various methods and techniques have been developed to explore the SW-GW interaction (for reviews, see [3,14]. The comparison of early use is mostly measurement methods (e.g., [15-18]), and the measurement methods mainly based on the point scale SW-GW interaction flux observation, or on the results of multi-point measurement extended to the site scale, suitable for accurate field scale research. Environmental tracer methods have been widely used to determine the SW-GW interaction, such as stable isotopes (deuterium and oxygen) [19,20], radioisotopes strontium [21], radium [22], radon [22-24], etc.

The hydro-chemical composition records the history of water migration and transformation in processes of hydrological cycles. Wang et al. [25] used the hydro-chemical analysis method to analyze the water source and mechanism of GW recharge in the Ejina Basin, their results showing that shallow phreatic and deep confined GW differ greatly in their compositions, while the discrepancy increases along the shallow GW flow paths. Martinez et al. [26] used long-range hydro-chemical data to study the SW-GW interactions, pointing out that the hydro-chemical analysis method should be combined with the environmental tracer method in practical application.

Numerical simulation methods have been widely used in studies on SW-GW interaction processes at various spatial scales [27-29]. It has been proven that numerical methods are not only applicable for small-scale researches [30,31], but also for regional scale researches [4,32]. In addition, the combination of numerical simulation and field measurement, hydrochemistry and isotope methods has been quite successful. For example, Ala-aho et al. [33] developed a combined SW-GW model to research GW-Lake interaction in the Esker aquifer, based on the long-term hydro-chemical data and environmental tracer method. Martinez et al. [26] used an integrated approach combining long-term hydrochemical data, hydraulic water level data and stable and radiogenic isotope hydrology for the determination of groundwater-surface interactions in headwater catchments.

In previous studies on SW-GW interaction, conclusions have been drawn that the the efficacy of an integrated approach combining hydrochemical data, isotope hydrology and numerical simulation, etc. are highly recommended [24,34], and basin-scale studies are likewise very important for revealing scientific problems. Field scale researches can accurately depict the local water flow system, but they cannot be solely used to study the SW-GW interaction in a whole basin. This problem can be solved by extending the study area to basin-scale research, assuming the availabilities of a great deal of supporting data and complex three-dimensional geological models. As such, there are relatively few studies on the scale of regional relationships [4].

Based on the combination of field surveys, numerical simulations, hydrochemistry and isotope analyses, three typical profiles of Yinchuan Plain are selected to study the hydrodynamic processes and effects of SW-GW interaction under different geological conditions. The main purposes of this study are to: (1) build hydrogeological models of typical profiles of Yinchuan Plain by combining the drilling data and geological survey; (2) analyze the hydrodynamic field characteristics of three profiles, revealing the SW-GW interaction mechanism and evolution process of the hydro-chemical field; and (3) explore the water interaction mode and its impacts in the arid areas of Northwest China. It is expected that the research can enrich the SW-GW interaction theory, providing guidance for the regional water resource management of Yinchuan Plain. 


\section{Methodology}

\subsection{Study Area}

Yinchuan Plain is located in the northern Ningxia Hui Autonomous Region of China, covering an area of $7790 \mathrm{~km}^{2}$ (Figure 1) [35-37]. It is in the middle-upper streams of the Yellow River and is bounded by Qingtong Gorge to the south, Shizui Mountain to the north, Helan Mountain to the west and the west margin of Ordos Plain to the east. The region belongs to moderate temperate inland arid climate, with the characteristics of extreme drought and little rainfall. The average potential annual precipitation is $184.7 \mathrm{~mm}, 70 \%$ of the annual rainfall occurs during June to September, and the average annual evaporation is $1748.44 \mathrm{~mm}$ from June to September, concentrated from March to October [38]. The mean annual air temperature is $8.92^{\circ} \mathrm{C}$ with the highest at $23.63^{\circ} \mathrm{C}$ in July and the lowest around $-7.73^{\circ} \mathrm{C}$ in January [35-38].

Yinchuan Plain can be divided into four geomorphic zones: mountain, plateau, plain and sand dunes. The western part is Helan Mountain, which is a high stone mountain with an overall trend of northeast $30^{\circ}$ and an elevation of $1500 \mathrm{~m}$ to $3200 \mathrm{~m}$. The middle part is the plain, composed of the piedmont diluvial sloping plain, alluvial-proluvial plain and river-lake plain [35-37]. Ditches, lakes and farmland are widely distributed. The cultivation history reaches nearly 2000 years. The east region is Taolin Salt Plateau of Ordos, with an elevation of $1300 \mathrm{~m}$ to $1600 \mathrm{~m}$. The edge of the plateau is connected to Yinchuan Plain by a steep ridge, influenced by the erosion and cutting of the Yellow River. The sand dunes are mainly composed of fine sand with certain mobility, and it is a landscape greatly affected by GW and climate such as rainfall and wind speed.

Water as a resource in Yinchuan Plain is mainly supplied by the Yellow River, which is located on the east side of the plain, with a total length of about $191 \mathrm{~km}$, and it is a perennial river carrying a large amout of sediment with an average salinity of $0.4 \mathrm{~g} / \mathrm{L}[35,39]$. There is a reservoir in the upper reaches of the study area to regulate and store the flow of the Yellow River, so the river level is relatively stable throughout the year in the study area. In addition to the main stream of the Yellow River, there are other large rivers in the area, such as the Kuishui River (originating from Gansu Province before finally joining the Yellow River) [36,39]. Yinchuan Plain is one of the oldest irrigation areas in China, with many irrigation channels and discharge ditches stretching all over the plain, such as Huinong Canel, West Canel, Qin Canel, etc. (Figure 2c). Furthermore, there are many short gullies in the surrounding mountains flowing into the Yellow River directly, providing a certain amount of runoff recharges to the piedmont [40].

The Yinchuan Plain has a land area of $7090 \mathrm{~km}^{2}$. The agricultural land is $4341 \mathrm{~km}^{2}$ including paddy fields, irrigated land, vegetable gardens, orchards, etc., mainly distributed in the plains on both sides of the Yellow River. The construction land is $1064 \mathrm{~km}^{2}$, including residential areas, industrial and mining land, transportation and water conservancy facilities. Other unused land is $1685 \mathrm{~km}^{2}$, including grassland, sandy land, swamp land, lake, river, tidal flat land, wetland, etc.

The GW in Yinchuan Plain is mainly pore water in Quaternary loose rocks. According to the analysis of geological, geomorphological and hydrogeological conditions and borehole data in the study area, it can be divided into single phreatic aquifer and multilayer aquifer system $[35,36]$. The single phreatic aquife are mainly distributed in the alluvial-diluvial fan area of the Yellow River in the south of Yinchuan Plain (I Zone in Figure 1), the piedmont plain area of Helan Mountain (II Zone in Figure 1), and the Yellow River floodplains in the northeast (III Zone in Figure 1). The lithology is mainly dominated by coarse sand, and the occasional cohesive soil is mostly lenticular in distribution, while the upper and lower hydraulic connections are good, thus forming a single hydrogeological structure. The multi-layer aquifer system is mainly distributed in the vast plains outside the single GW areas of Helan Mountain and the alluvial fan of the Yellow River (IV Zone in Figure 1). Sand and clayey soil layers are distributed alternately to form a multi-layer hydrogeological structure. In the multi-layer aquifer system, the quaternary water-bearing rock series can be divided into four water-bearing rock groups above approximately $400 \mathrm{~m}$ in depth; from top to bottom, they are the phreatic aquifer group, 
the first confined aquifer group, the second confined aquifer group and the third confined water; additionally, there are relatively continuous acquirers with lower permeability between aquifer groups in general [41].

\subsection{Typical Profiles Settings}

According to the lithology of the regional aquifer and the characteristics of GW flow, three typical profiles are selected to study interaction of the SW-GW system (as shown in Figure 1).

Profile 1: The 2D slice starting from Helan Mountain in the west, passing through piedmont floodplain, alluvial-proluvial plain, alluvial plain, and ending at the Ordos Plateau in the east. It lies in the nearly W-E direction, with a length of $58 \mathrm{~km}$. This slice has the same direction of GW mainstream, covering all geological geomorphic types in Yinchuan Plain. Moreover, it passes through several major faults in Yinchuan Plain with spring outcrop.

Profile 2: This slice is located in the southern part of Yinchuan Plain, passing through the alluvial-diluvial plain, alluvial plain and hilly platform from northwest to southeast, with a length of $38 \mathrm{~km}$.

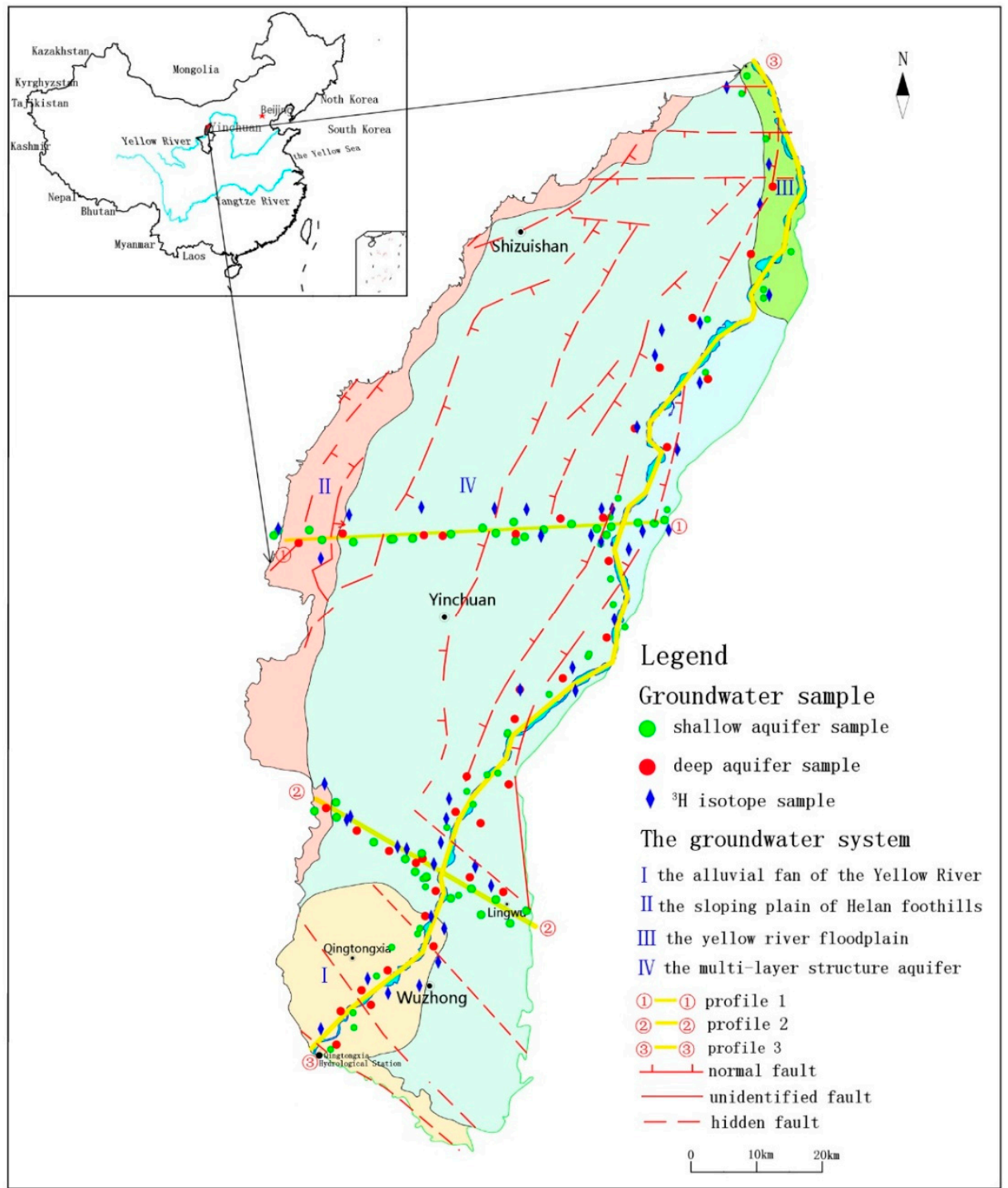

Figure 1. Sketch map of hydrogeology and profiles location in Yinchuan plain. 
Profile 3: The slice is along the Yellow River, which is the main river from south to north through Yinchuan Plain. The GW is closely connected with the Yellow River water in this basin, while the Yellow River water is used to irrigate the plain area, flowing back to the Yellow River in the form of drains and GW. Therefore, the river-basin water cycle system is dominated by the river, and the selected location coincides with the purpose of this study.

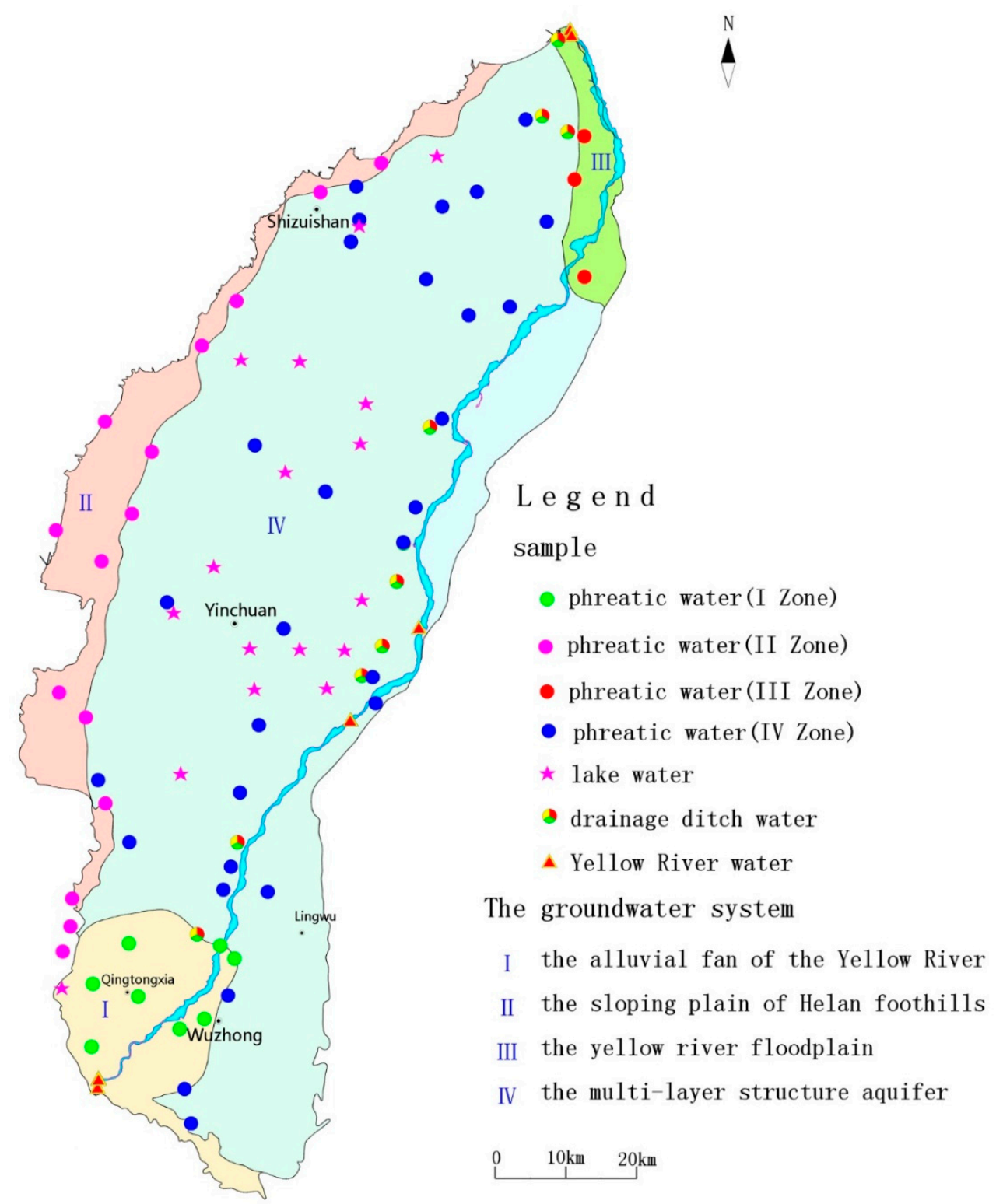

(a)

Figure 2. Cont. 


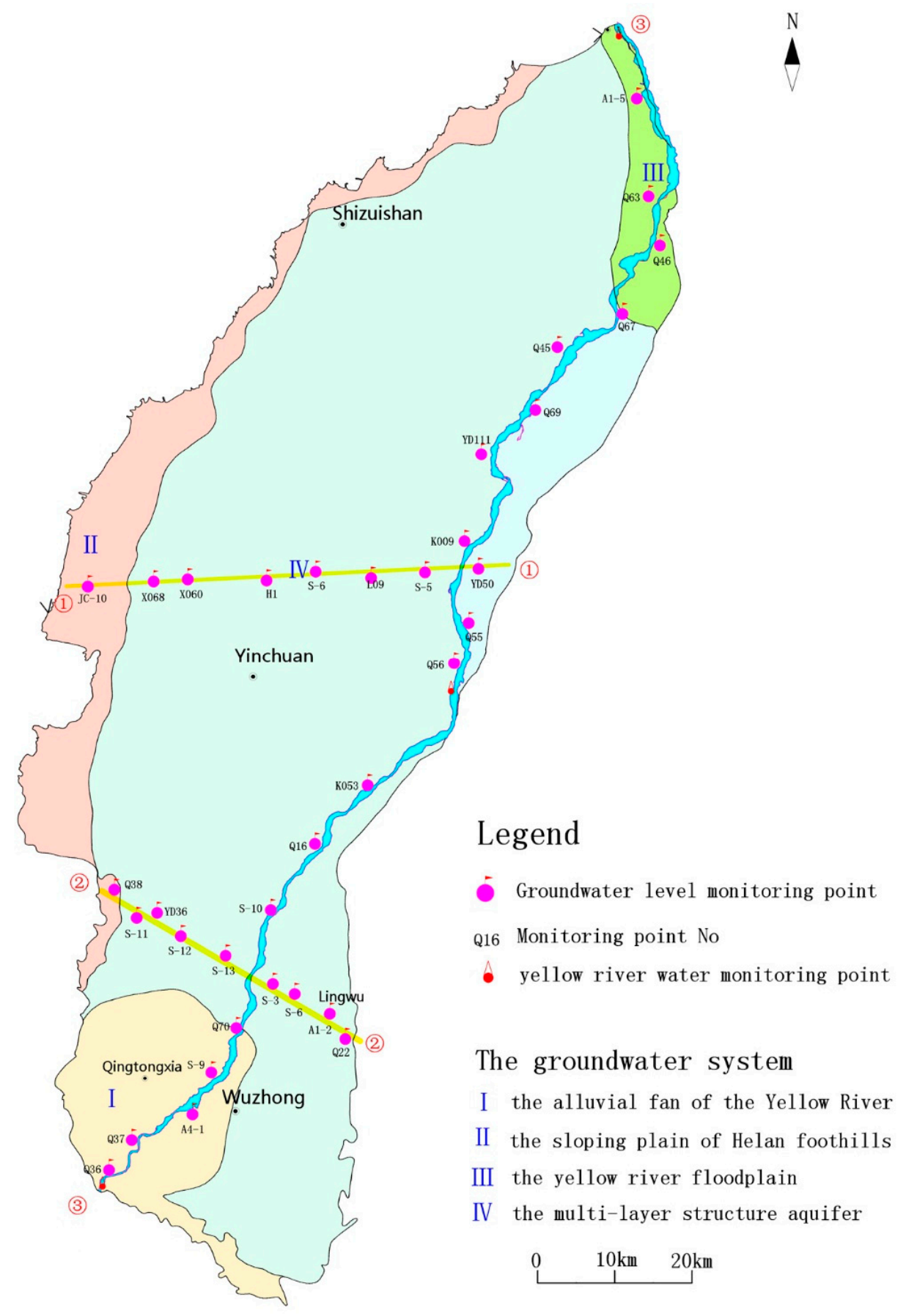

(b)

Figure 2. Cont. 


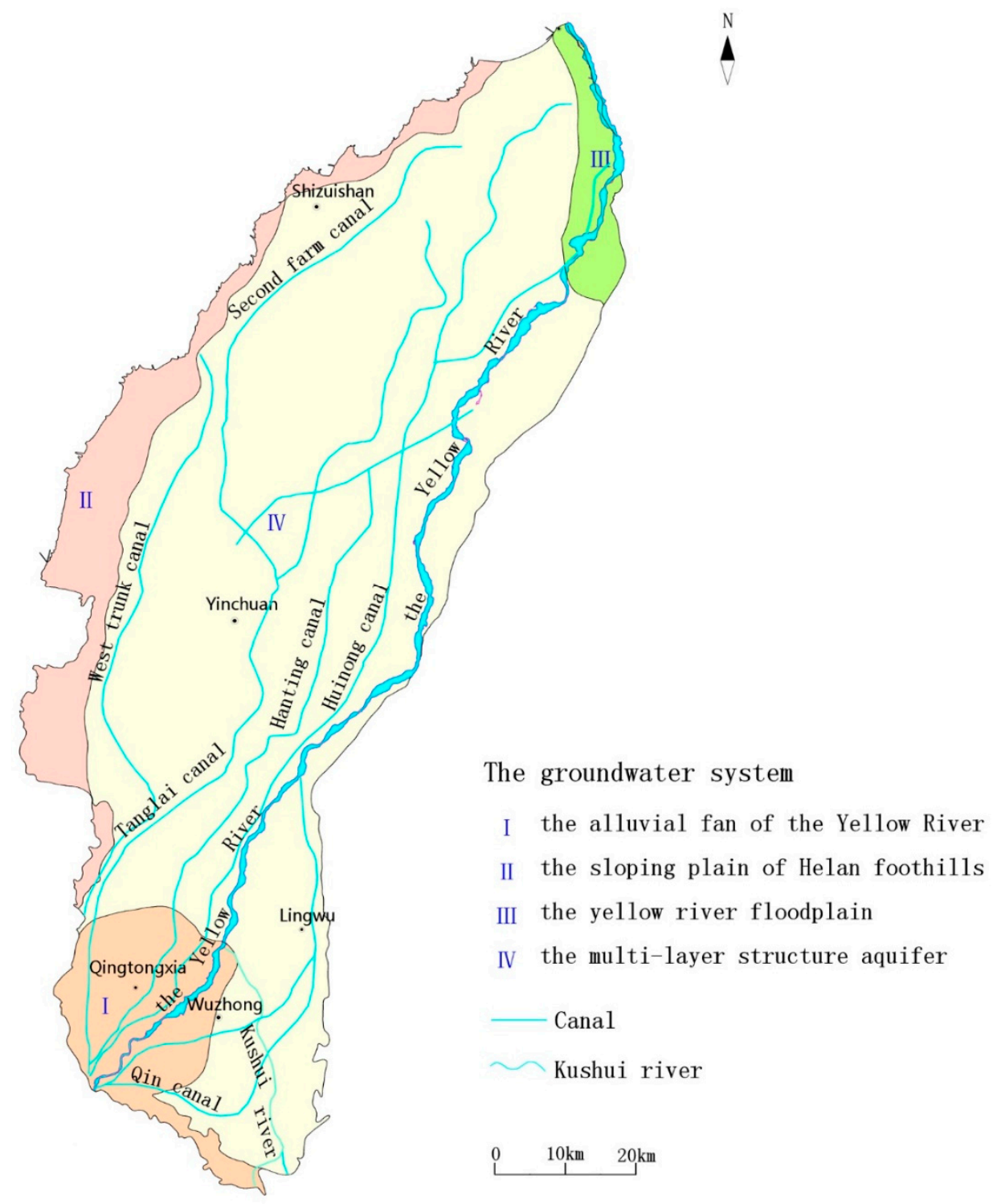

(c)

Figure 2. (a). The sample points of $\mathrm{D}$ and ${ }^{18} \mathrm{O}$ in study area. (b). The spatial distribution of water level monitoring point. (c). The spatial distribution of river system.

\subsection{Methods and Data Collection}

An integrated approach is employed to characterize hydrodynamic processes of the SW-GW system in this study, including (1) geological drilling and hydrogeological survey; (2) hydro-chemical investigation; (3) isotope analysis; and (4) numerical simulation.

The drilling data are used to establish the geological structure of the profile, and the hydrochemistry method is used to reveal the source, origin and migration law of the water body by recording the migration and transformation information of the water body during the course of runoff. The deuterium and oxygen isotopes of the water body are used to investigate the source of water body recharge and the mutual transformation relationship between different water bodies [26,42]. Radioactive tritium isotopes are used to calculate the age and renewal rate of GW, to indicate water cycle information and to mark migration of the water source in the aquifer [43].

A total of $110 \mathrm{GW}$ samples are collected for hydro-chemical analysis, including 66 shallow and 44 deep GW samples (Figure 1). 122 deuterium and oxygen stable isotopes of water samples are collected, including 61 shallow GW samples, 17 lake water samples, 27 water samples from drainage 
ditches, 11 Yellow River water samples and 6 spring water samples (Figure 2a). The data are derived from data published by Qian et al. [36]. The shallow GW is divided into 4 groups according to the GW system as shown in Figure 2a. According to the long-term monitoring data of Yinchuan Station in the Global Network of Isotopes in Precipitation (GNIP) Database of International Atomic Energy Agency, the weighted averages of $\delta^{2} \mathrm{H}$ and ${ }^{18} \mathrm{O}$ in precipitation are $-42.7 \%$ and $-6.34 \%$. The $\delta^{2} \mathrm{H}$ and $\delta^{18} \mathrm{O}$ equation of atmospheric precipitation is obtained as follows in terms of the least square method: $\delta^{2} \mathrm{H}=7.22 \delta^{18} \mathrm{O}+5.5$.

The river water level monitoring data are obtained from the Qingtongxia Hydrological Station. The GW level monitoring data are derived from the Hydrogeological and Environmental Geological Survey and Evaluation Project of Ningxia Economic Zone along the Yellow River [38] and the National GW Monitoring Project [44]. The time period of monitoring data expands from April 2014 to December 2015 , and distribution of the water level monitoring points on the profile is shown in Figure $2 b$.

94 groups of GW tritium isotope samples are collected, and the tritium data of 54 sets of isotopes on the profile (Figure 1) are derived from data published by Chen et al. [45]. Radioactive tritium is used to calculate mathematical physical models of GW age, mainly including the piston flow model (PFM), exponential model (PEM), exponential-piston model (EPM) and dispersion model (DM) [46]. Based on the geological conditions of Yinchuan Plain, the DM is selected to estimate the tritium age of GW samples. First, the tritium content of the local meteoric water is restored, and the tritium monitoring data of the meteoric water (1986-1992 and 1999-2000) could be obtained from the Yinchuan Station of International Atomic Energy Agency (IAEA). According to the difference correlation method [47], Doney model method [48], triangle extrapolation method (surrounding stations are Hong Kong, Harbin, and Urumqi) and Vienna-related method [49], the tritium contents in the meteoric water during the four periods (1953-1959), (1960-1986), (1992-2004) and (2004-2009) are restored, respectively. Meanwhile, the tritium in the meteoric water after 2010 has been restored to the pre-nuclear explosion level of about 18TU, affected by rainfall [50]. FlowPC 3.1 [51] and the DM are selected to calibrate the tritium age of GW samples. During calculation, the optimal fitting of the output tritium content calculated with the model is carried out by using the sampling data of different years at the same sample site, so that the accurate GW dispersion parameters of different hydrogeological units and the retention time of the sample site are obtained. Finally, the parameters are applied to the corresponding hydrogeological units, and the retention time of the tritium model of individual samples in certain units was calculated using this method [45].

Regarding the average annual GW renewal rate, the full mixing model proposed by La Salle et al. [52] is adapted; assuming that GW is completely mixed in the aquifer, the annual average renewal rate of the aquifer is calculated by the radioactive decay of ${ }^{3} \mathrm{H}$, and the annual input in a time step for the year. The model expression is as follows: assuming that the aquifer is stable; that is, the input of water is equal to the output and the GW is continuously recharged and completely mixed. The tritium content in the GW is calculated by radioactive decay and annual input variations:

$$
{ }^{3} H_{g w i}=\left(1-R_{i}\right)^{3} H_{g w i-1} e^{-\lambda}+R_{i}^{3} H_{0 i}
$$

where, ${ }^{3} H_{g w i}$ is the ${ }^{3} \mathrm{H}$ content (TU) of GW in the year $i$, and $H_{g w i-1}$ is the ${ }^{3} \mathrm{H}$ content (TU) of GW in the year $i-1 ; H_{0 i}$ is the ${ }^{3} \mathrm{H}$ content (TU) of input water in year $i ; R_{i}$ is the annual renewal rate (\%/a) in year $i ; \lambda$ is the radioactive decay constant, at 0.05626/a. Calculation is made from 1952 (before the atmospheric nuclear explosion), the ${ }^{3} \mathrm{H}$ content of GW before 1952 is $10 \mathrm{TU}$, then ${ }^{3} \mathrm{H}$ concentration in GW in 1952 is:

$$
{ }^{3} \mathrm{H}_{g w 1952}=\frac{{ }^{3} H_{0}}{\lambda / R+1}
$$

If the recharge has a linear relationship with the annual precipitation, then the annual renewal rate $\left(R_{i}\right)$ is equal to the average renewal rate $(R)$ multiplied by the percentage of the annual precipitation $\left(P_{i}\right)$ to the annual average precipitation $\left(P_{m}\right)$. Taking into account the maximum precipitation value 
$\left(P_{t}\right)$ at which recharge takes place, this relationship is usually not fully applicable in arid and semi-arid areas, so the annual renewal rate in this work is expressed as follows [53]:

$$
R_{i}=\frac{R\left(P_{i}-P_{t}\right)}{P_{m}-P_{t}}
$$

According to the meteorological data of Yinchuan Plain Meteorological Station since 1952, the atmospheric rainfall in 1980 is selected as the maximum precipitation $(193.9 \mathrm{~mm})$. In the calculation of Equations (1) and (2) of the full mixing model, the relation curve between ${ }^{3} \mathrm{H}$ isotope in GW and the annual renewal rate can be obtained; then, the type curve method is adopted according to the measured ${ }^{3} \mathrm{H}$ value of GW, and the GW renewal rate at the sampling point can be obtained [54].

\subsection{Numerical Model Building}

The numerical model of GMS software developed by Aquaveo LLC. is adopted in this paper to explore the hydrodynamic process of the SW-GW interaction under different patterns based on two-dimensional steady-state flow in the section. Every model of the three typical profiles was generalized into a stable GW system with heterogeneous anisotropy, according to characteristics of the aquifer structure, lithology and GW flow.

Profiles 1 and 2 are selected along the direction of groundwater flow, and groundwater flow in the east-west direction dominates the flow field. The groundwater regime indicates that the groundwater levels are relatively steady [55]. Therefore, Profiles 1 and 2 in the east-west direction were selected for this study, while Profile 3 was chosen to be parallel to the Yellow River to study the interaction between the river and groundwater, as well as to investigate the relative magnitude of flow in the north-south direction. Besides, steady-state 2D numerical models for these 3 profiles were studies to reveal more detailed features of vertical flows while maintaining computational cost in an affordable range.

The boundary conditions of Profiles 1 and 2 are as follows: The west lateral boundary is the border between the Quaternary of Yinchuan Plain and the bedrock of Helan Mountain; the stratum lithology on the left of the border is mainly Tertiary bedrock; the GW recharge of Helan Mountain to the plain is mainly manifested as the underseepage in the process of mountain flood dispersion; the movement of GW is mainly vertical; therefore, the west boundary is generalized as an impermeable boundary. Floods pass through the piedmont alluvial fan of Helan Mountain, most of them infiltrating to recharge the GW, so the west upper part of this area is set as the constant flow rate boundary, and the wells module is used for constant flow recharge. On the alluvial-proluvial plain and fluviolacustrine plain of the study area, the upper boundary is a free surface of the phreatic aquifer, which is closely related with irrigation channels, agricultural irrigation, precipitation, evaporation of submerged surface and drainage ditches in the areas. The GW level is mainly affected by agricultural irrigation, and its variation range is small. The phreatic water level is used as a constant head boundary in order to better control the flow simulation, and the water elevation is set as a constant head. The east boundary of Profiles 1 and 2 is the border between Yinchuan Plain and Ordos Platform, it is generalized as a constant flow rate boundary; the bottom boundaries of Profiles 1 and 2 are defined in the bottom of the third confined aquifer group in Yinchuan Plain with a large buried depth and very small GW exchange; so such boundaries are generalized as impermeable boundaries (Figure 3a). The upper boundary of Profile 3 is a constant head boundary and the head value is the water level of the Yellow River, while the two sides (east and west) are flow rate boundaries. 


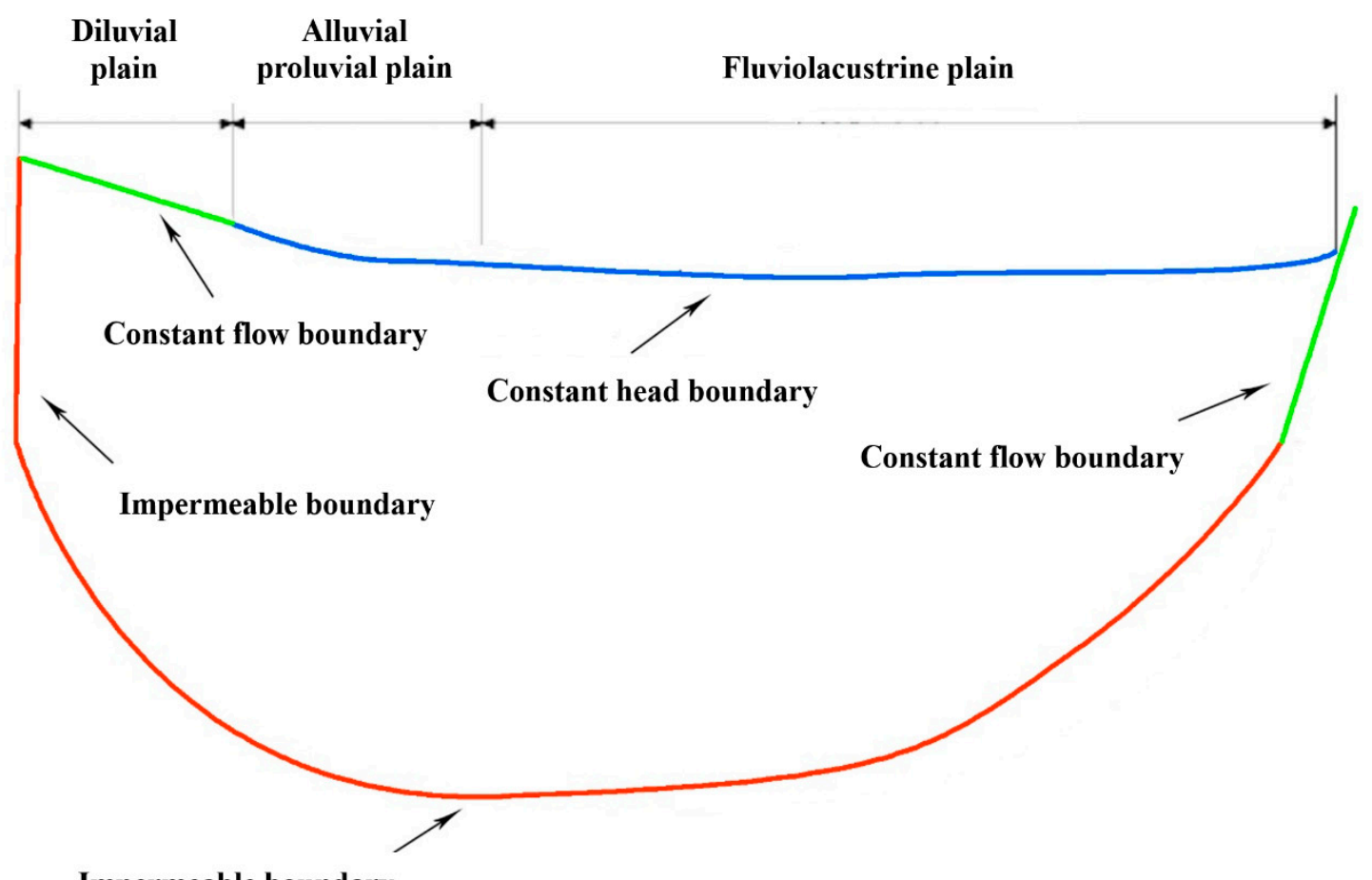

Impermeable boundary

(a)

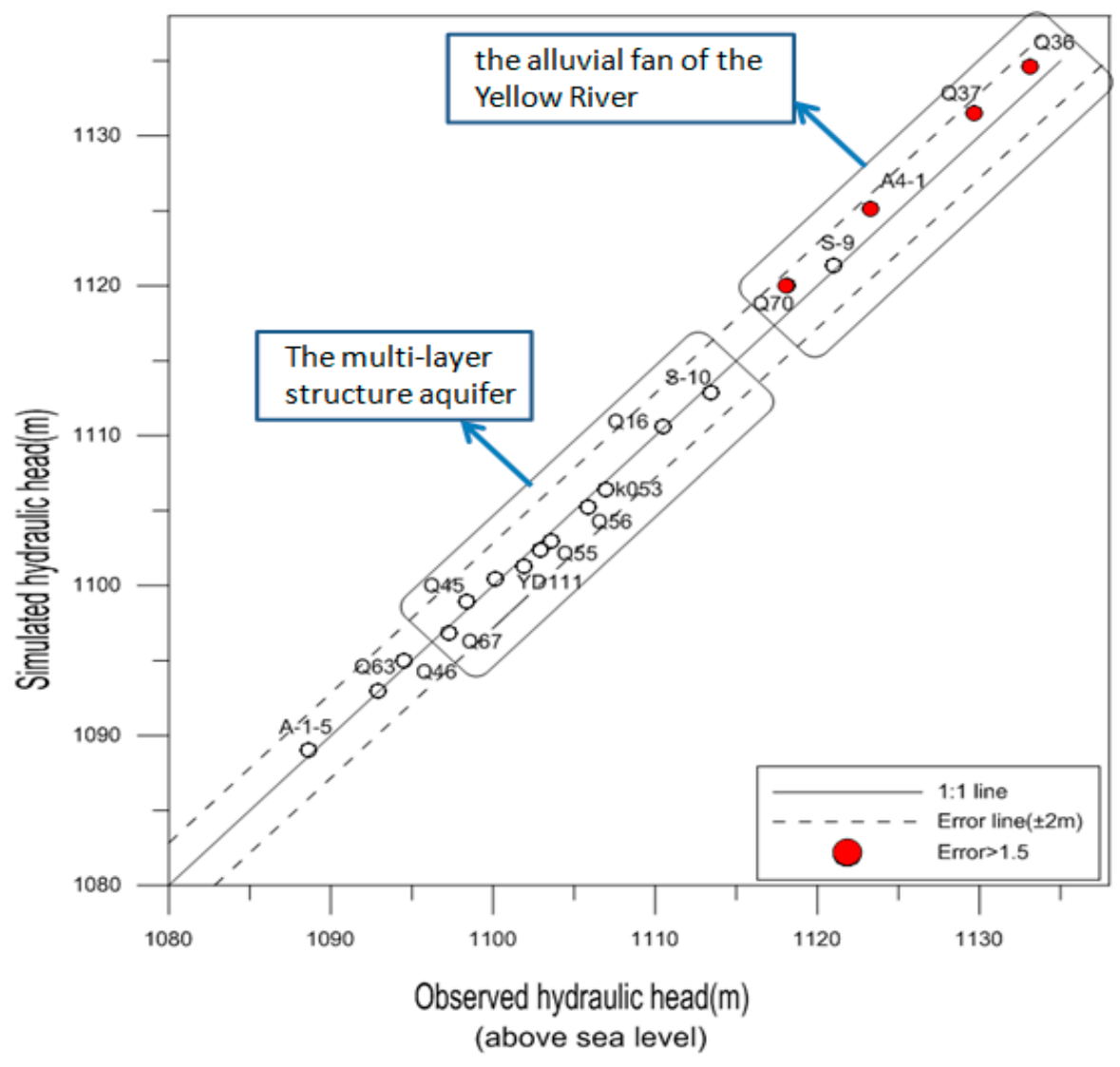

(b)

Figure 3. (a). Boundary conditions of Profiles 1 and 2. (b). Comparison of observed and simulated hydraulic head (above sea level) values along the Yellow River. 


\section{Results}

\subsection{Groundwater Flow Modeling}

Wang [55] established numerical models for Profiles 1 and 2 and validated these models using the water level data in 2014 and 2015. In Profile 3, 18 GW level monitoring points (see Figure 2b for locations) along the Yellow River in 2014 and 2015 are taken as the fitting targets, and the parameters are adjusted and corrected by using the trial-and-error correction method. The GW level simulation values in the calibrated model are compared with the observed values (Figure $3 \mathrm{~b}$ ). The simulation results show that the wat'er level fitting is relatively poor in the upper Yellow River alluvial fan area (the errors of red dots such as Q36 and Q37 are between $1.4 \mathrm{~m}$ and $1.9 \mathrm{~m}$ ), their larger errors result from the larger hydraulic gradient of GW and more significant seasonal fluctuation of GW level in the area [56]. The fitting effect of the water level in the plain area is good, with an error of within $0.6 \mathrm{~m}$, and the error is mainly due to the heterogeneity and anisotropy of the medium [57]. The overall error of Profile 3 is calculated by the root mean squared error (RMSE), the RMSE of GW level simulation results is only $0.93 \mathrm{~m}$, so the simulation can reflect the characteristics of GW flow field and can be used to reveal GW flow mode in the modeled hydrogeological profile.

The initial parameters of the model in Profile 3 are based on drilling data and empirical values, and previous studies $[38,58]$ are referred; the variation range of the horizontal permeability coefficient $\left(\mathrm{K}_{\mathrm{h}}\right)$ is $10^{2}-10^{-3} \mathrm{~m} / \mathrm{d}$, and the vertical permeability coefficient $\left(\mathrm{K}_{\mathrm{v}}\right)$ is $0.1-0.2$ times the horizontal ones; the variation range of porosity ratio is $0.35-0.55$. The model parameters after calibration are shown in Table 1.

Table 1. Estimated parameters of different lithology.

\begin{tabular}{|c|c|c|c|}
\hline Lithology & $\begin{array}{l}\text { Horizontal Hydraulic Conductivity } \\
\qquad K_{h}\left(m \cdot d^{-1}\right)\end{array}$ & $\begin{array}{l}\text { Anisotropy Ratio } \\
\mathbf{K}_{\mathbf{h}} / \mathbf{K}_{\mathbf{v}}\end{array}$ & Porosity \\
\hline Gravel & 35 & 10 & 0.35 \\
\hline Medium sand & 6.8 & 10 & 0.40 \\
\hline Fine sand & 2.5 & 10 & 0.42 \\
\hline Sandy loam & 0.07 & 5 & 0.45 \\
\hline loam & 0.05 & 5 & 0.48 \\
\hline clay & 0.002 & 5 & 0.55 \\
\hline
\end{tabular}

\subsection{Profile 1}

Figure 4 shows the hydrogeological structure and SW-GW flow system in Profile 1. In this system, SW and GW transform 3-5 times. GW flows mainly from the single GW area in the west to the lake area in the middle of the plain, and to the Yellow River. This profile contains a three-stage SW-GW flow system; namely, the local flow system, intermediate flow system and regional flow system. Among them, the depth of the local flow system is about $100 \mathrm{~m}$, and the influence length-scale is about $2-5 \mathrm{~km}$. There are several local GW flow subsystems from the piedmont diluvial sloping plain to the central alluvial-diluvial plain and fluvial plain. Simulation results have shown that there is a rapid local GW flow system with a seepage rate of $0.02-0.07 \mathrm{~m} / \mathrm{d}$ in the piedmont and alluvial-diluvial fan nearby, and the aquifer is mainly recharged from precipitation and surface runoff. In the alluvial and lacustrine plain, there are several local GW flow subsystems with a seepage rate of about $0.01 \mathrm{~m} / \mathrm{d}$. The depth of the intermediate flow system is about $200 \mathrm{~m}$, and the influence width is about $20 \mathrm{~km}$. The GW is eventually discharged to Yuehai Lake, and the seepage rate of the GW is $0.01-0.05 \mathrm{~m} / \mathrm{d}$. The depth of the regional flow system is $>300 \mathrm{~m}$, and the influence width is about $40 \mathrm{~km}$. The GW discharges to the Yellow River, finally. According to the isotope analysis results, the age of the shallow GW in the alluvial and diluvial fan in the piedmont is less than 30 years, and the GW renewal rate is $0.4-1.2 \% \cdot \mathrm{a}^{-1}$. In the alluvial plain and lacustrine plain, the age of the shallow GW is less than 65 years, and the GW 
renewal rate is $1.3-7 \% \cdot \mathrm{a}^{-1}$; the age of deep GW is $>65$ years, and the GW renewal rate is slow at around $0.1-0.5 \% \cdot \mathrm{a}^{-1}$.
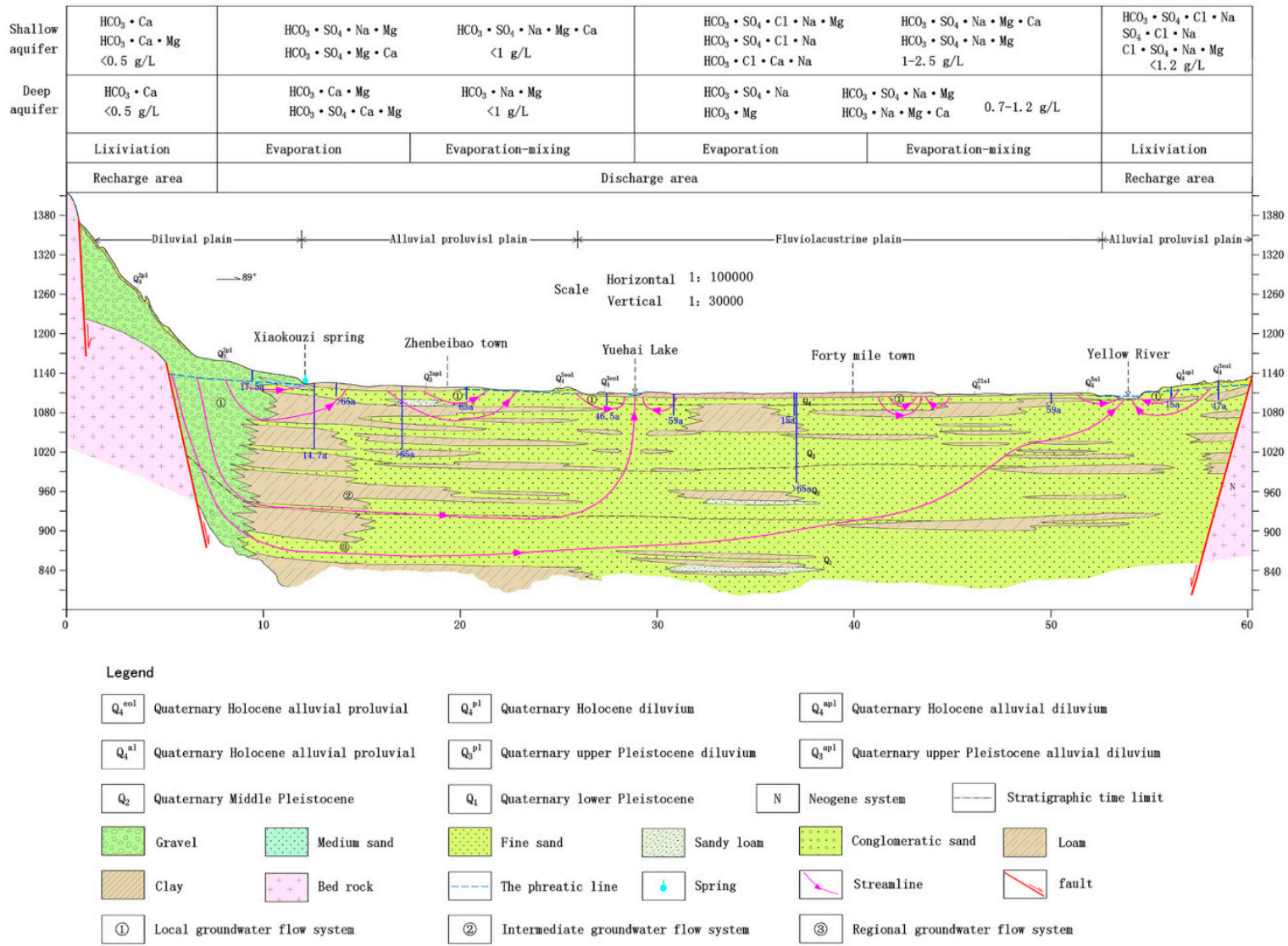

Figure 4. Hydrogeological structure and SW-GW interaction model in Profile 1.

The hydro-chemical types of GW show obvious zonation along the direction of GW flow from the piedmont to the Yellow River, driven by the hydrodynamic process of SW-GW interaction. In the local flow system, the chemical types of GW in the piedmont plain of Helan Mountain are mainly $\mathrm{HCO}_{3} \bullet \mathrm{Ca}, \mathrm{HCO}_{3} \bullet \mathrm{Ca} \bullet \mathrm{Mg}$. The TDS is about $0.2-0.3 \mathrm{~g} / \mathrm{L}$, and the hydrochemistry is mainly dominated by dissolution and filtration $[37,39]$. On the alluvial plain, the anion chemical type of GW was transformed from $\mathrm{HCO}_{3} \bullet \mathrm{SO}_{4}$ to $\mathrm{HCO}_{3} \bullet \mathrm{SO}_{4} \bullet \mathrm{Cl}$, and the cation was transformed from $\mathrm{Ca}, \mathrm{Ca} \bullet \mathrm{Na}$ or $\mathrm{Ca} \bullet \mathrm{Mg}$ type to $\mathrm{Na} \bullet \mathrm{Mg}$ or $\mathrm{Na}$ type from the west to the east. The TDS varied from 0.6 to $2.5 \mathrm{~g} / \mathrm{L}$, and the hydro-chemical reaction was mainly dominated by evaporation [37,39]. In the intermediate flow system, the chemical types of GW in the piedmont plain are mainly $\mathrm{HCO}_{3} \bullet \mathrm{Ca} \bullet \mathrm{Mg}$ type, while in the alluvial-diluvial plain and alluvial plain, the chemical types of GW are mainly $\mathrm{HCO}_{3} \bullet \mathrm{SO}_{4} \bullet \mathrm{Ca}$, $\mathrm{HCO}_{3} \bullet \mathrm{Na} \bullet \mathrm{Mg}$ type, and the TDS is less than $1 \mathrm{~g} / \mathrm{L}$.

\subsection{Profile 2}

Figure 5 shows the hydrogeological structure of Profile 2. It can be seen that GW flows into the Yellow River from east and west sides, and SW and GW transform 2-3 times. It contains a two-stage GW circulation system. The seepage path is about $3-8 \mathrm{~km}$ long in the local flow system with a depth of about $60-80 \mathrm{~m}$, and the GW seepage rate is about $0.01-0.05 \mathrm{~m} / \mathrm{d}$. The seepage path of the intermediate flow system is generally about $12-20 \mathrm{~km}$ long and up to $320 \mathrm{~m}$ deep, and the GW seepage rate is about $0.0004-0.02 \mathrm{~m} / \mathrm{d}$. As shown by the isotope analysis results, the age of GW in the local flow system is shorter than 65 years, and the renewal rate of GW is mostly $0.3-15 \% \cdot \mathrm{a}^{-1}$, with a strong alternation of GW circulation and a strong renewal capability. The age of GW in the intermediate flow system is longer than $65 \mathrm{a}$, with a renewal rate of $0.1-0.2 \% \cdot \mathrm{a}^{-1}$, representing a slow circulation. 
According to hydro-chemical analysis, in the western part of the Yellow River, the GW in the local flow system is dominated by $\mathrm{HCO}_{3} \bullet \mathrm{SO}_{4}$ type, and the TDS is less than $1 \mathrm{~g} / \mathrm{L}$. GW in the intermediate flow system evolved from $\mathrm{HCO}_{3} \bullet \mathrm{SO}_{4} \bullet \mathrm{Cl}$ type to $\mathrm{Cl} \bullet \mathrm{SO}_{4}$ type, and the TDS is about $1 \mathrm{~g} / \mathrm{L}$. In the eastern part of the Yellow River, the chemical types of shallow and deep GW are mainly $\mathrm{Cl}_{\bullet} \bullet \mathrm{SO}_{4} \bullet \mathrm{Na}$

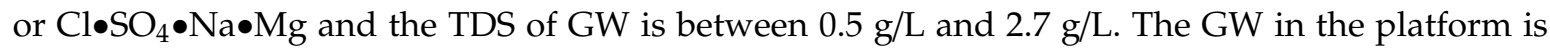
dominated by $\mathrm{SO}_{4} \bullet \mathrm{Cl} \bullet \mathrm{Na}$ type, mainly affected by precipitation and lixiviation (37), and the TDS is about $0.6-2.8 \mathrm{~g} / \mathrm{L}$.

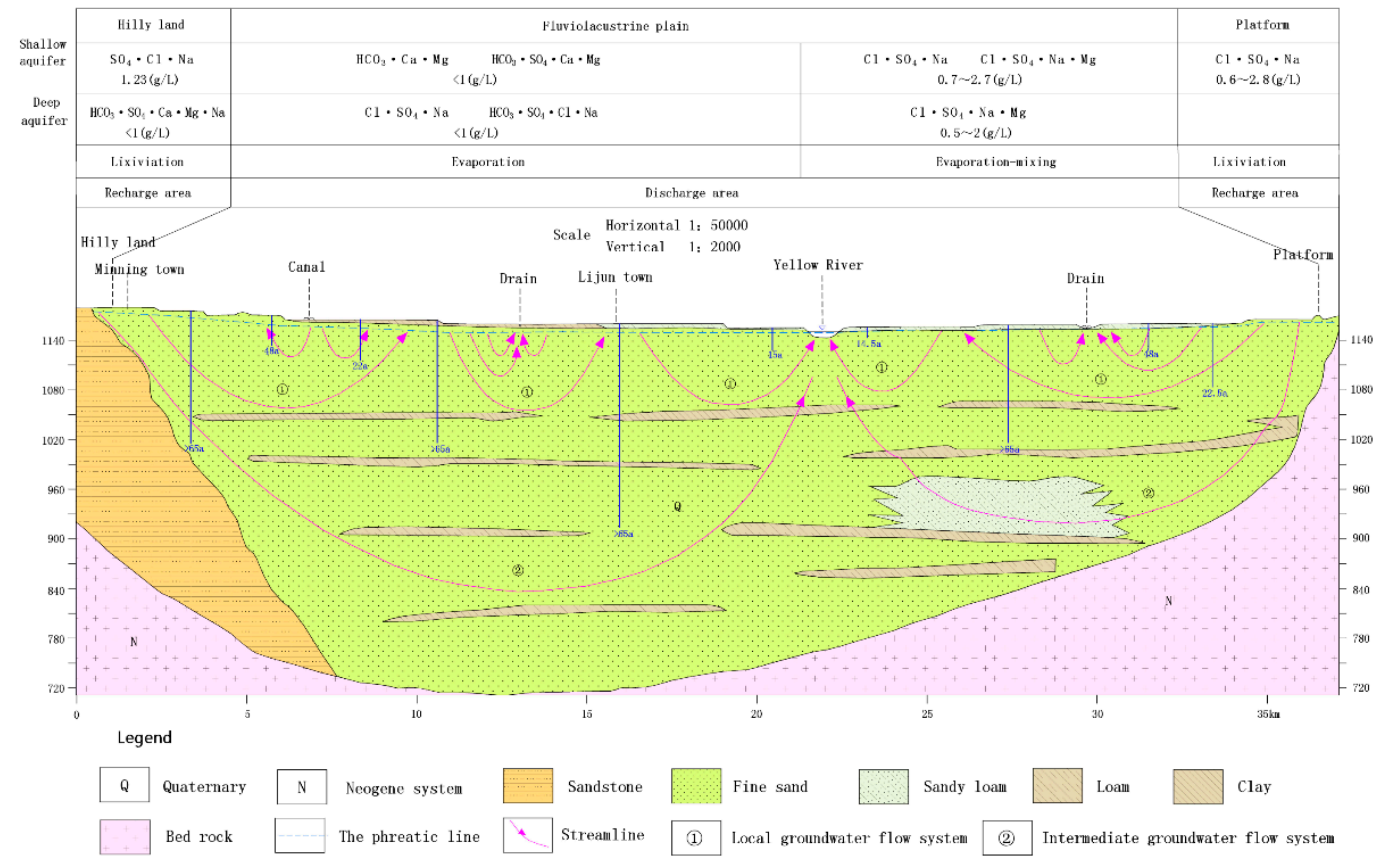

Figure 5. Hydrogeological structure and surface-GW interaction model in Profile 2.

\subsection{Profile 3}

Figure 6 shows the hydrogeological structure of Profile 3, containing local and intermediate flow systems, with depths within $80 \mathrm{~m}$ and $180 \mathrm{~m}$, respectively, and SW and GW transforming 2-3 times, forming a GW flow system dominated by rivers. In the upstream of the Yellow River, the seepage path in the local flow system is $8-12 \mathrm{~km}$, with a seepage rate of about $0.0002-0.0006 \mathrm{~m} / \mathrm{d}$ (Figure 7), the seepage path in the intermediate flow system is about $35 \mathrm{~km}$, with a seepage rate of $0.0002-0.0004$ $\mathrm{m} / \mathrm{d}$. The GW is mainly recharged by river, precipitation and agricultural irrigation. In the middle and lower reaches of the Yellow River, the seepage rate of the local flow subsystem is about 0.0004-0.0006 $\mathrm{m} / \mathrm{d}$, and the seepage path length is $15-35 \mathrm{~km}$. The aquifer is mainly supplied by river seepage and lateral GW runoff on both sides. Isotope analysis results show that the ages of GW along both sides of the Yellow River are short, especially the local flow system of the upper reaches, whose renewal rate of GW is $5-50 \% \mathrm{a}^{-1}$. The renewal rate of GW is relatively slow and is around $0.1-6 \% \mathrm{a}^{-1}$ in the intermediate flow system.

The hydro-chemical type of the Yellow River water in the upstream is dominated by $\mathrm{HCO}_{3} \bullet \mathrm{SO}_{4} \bullet \mathrm{Ca} \bullet \mathrm{Mg} \bullet \mathrm{Na}$, and the hydro-chemical type of shallow GW is mainly $\mathrm{HCO}_{3} \bullet \mathrm{SO}_{4} \bullet \mathrm{Ca} \bullet \mathrm{Mg}$ and $\mathrm{HCO}_{3} \bullet \mathrm{SO}_{4} \bullet \mathrm{Ca} \bullet \mathrm{Na} \bullet \mathrm{Mg}$ (similar to the chemical type of the Yellow River water), with varying TDS of $0.5-0.9 \mathrm{~g} / \mathrm{L}$ in the GW, indicating that there is a direct mutual recharge relationship between the Yellow River and GW. In the middle reaches of the Yellow River, the hydro-chemical types of shallow GW are diversified, including $\mathrm{HCO}_{3} \bullet \mathrm{SO}_{4} \bullet \mathrm{Ca} \bullet \mathrm{Mg}, \mathrm{HCO}_{3} \bullet \mathrm{Cl} \bullet \mathrm{Na} \bullet \mathrm{Mg}, \mathrm{SO}_{4} \cdot \mathrm{Cl} \cdot \mathrm{Na} \cdot \mathrm{Mg}$, $\mathrm{HCO}_{3} \bullet \mathrm{SO}_{4} \bullet \mathrm{Na} \bullet \mathrm{Mg} \bullet \mathrm{Ca}$, etc., and the TDS is $0.7-1.4 \mathrm{~g} / \mathrm{L}$. In the downstream, the chemical types of shallow GW are mainly $\mathrm{Cl} \bullet \mathrm{SO}_{4} \bullet \mathrm{Na} \bullet \mathrm{Mg}, \mathrm{Cl} \bullet \mathrm{SO}_{4} \bullet \mathrm{Na}, \mathrm{SO}_{4} \bullet \mathrm{Cl} \bullet \mathrm{Na}$ and $\mathrm{Cl} \bullet \mathrm{SO}_{4} \bullet \mathrm{HCO}_{3} \bullet \mathrm{Na} \bullet \mathrm{Mg}$, and the 
TDS is 1.5-9 g/L. The TDS of shallow GW changes from low to high along the Yellow River, and the TDS of deep GW is mostly less than $1 \mathrm{~g} / \mathrm{L}$.

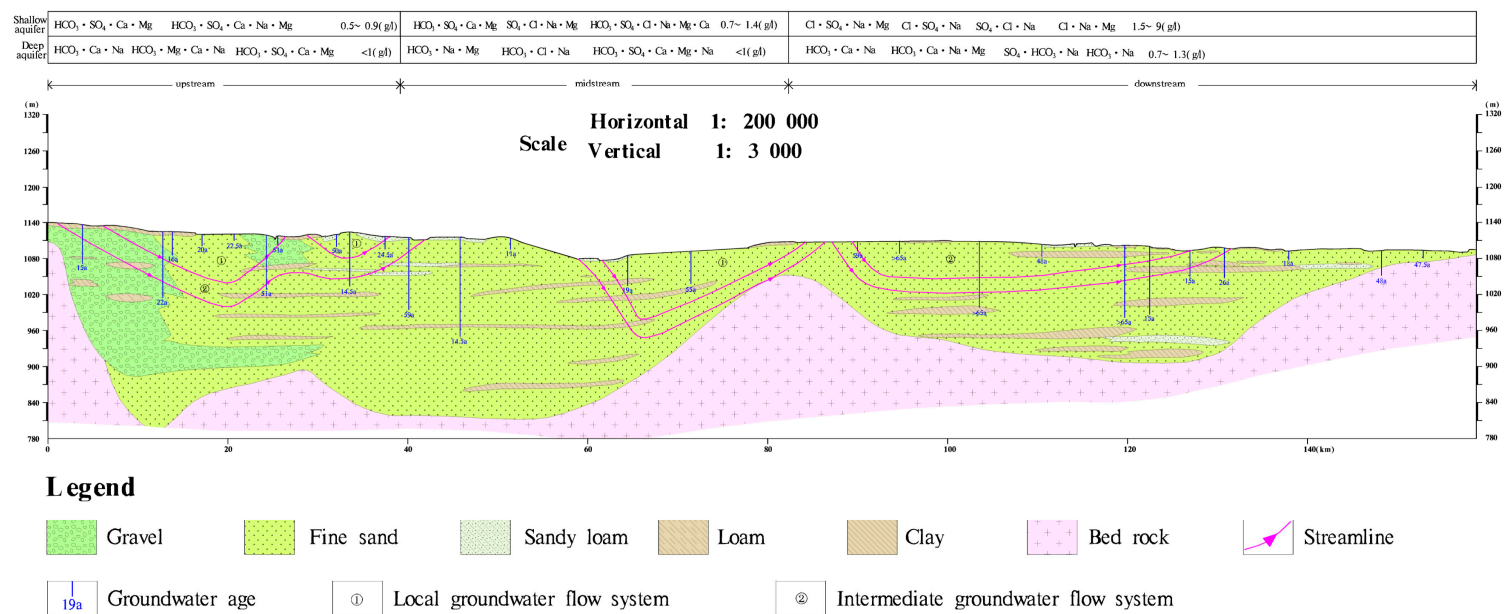

Figure 6. Hydrogeological structure and surface-GW interaction model in Profile 3.

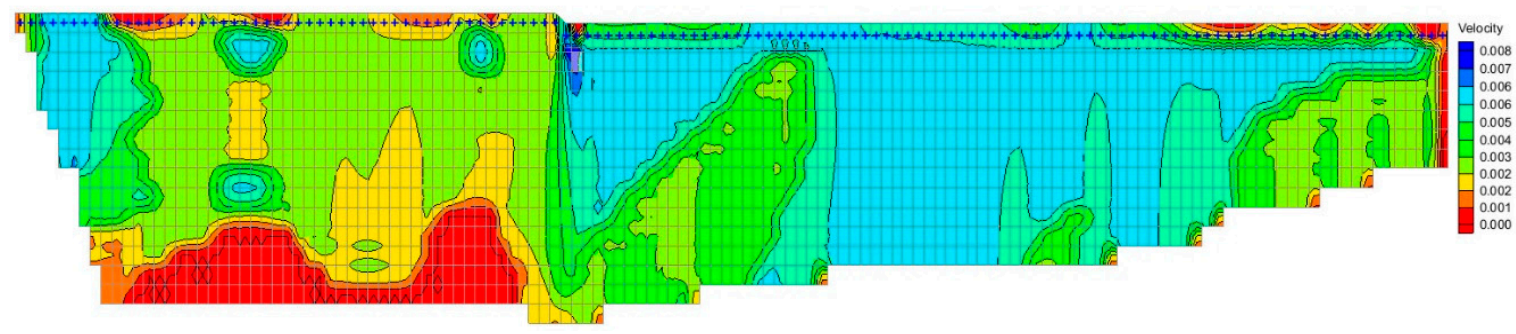

Figure 7. The average velocity in Profile 3.

\section{Discussion}

\subsection{Interpretation to Isotopes of SW-GW Interaction in Yinchuan Plain}

The GW samples of the alluvial-pluvial fan (II Zone in Figure 2) at the eastern foot of Helan Mountain are all located below this LMWL, which indicates that the recharge in this region has other sources in addition to the meteoric water. Some samples are substantially concentrated along the evaporation line defined by the surface lake water, which indicates that the proportion of local meteoric water recharge is relatively small, and that the main source of recharge should be the meteoric water from high-elevation areas with a smaller isotope ratio or ancient recharge during cold a climate. Since tritium can be detected in most samples, ancient recharge can be ruled out and GW should be recharged by the meteoric water from high-elevation areas in Helan Mountain. Some GW samples are distributed around the spring water sample, which indicates that there is a mutual recharge between spring water and GW. Qian et al. [36] believe that GW is recharged by spring water and meteoric water, and the proportion of the recharge by spring water is larger, and the lateral recharge source is partly reflected in the piedmont of Helan Mountain, which proves the existence of local water flow system in the piedmont in Profile 1. The samples of Zone I are located in the alluvial-pluvial fan of the Yellow River in the upper reaches of Yinchuan Plain. As shown in Figure 8A, the isotope ratios of GW samples in this zone are all less than the average value of LMWL of Yinchuan. $\delta^{18} \mathrm{O}$ varies widely and is close to the mean value of the Yellow River water, which indicates that its recharge source is the Yellow River. During the recharge process, it is affected by evaporation, and the recharge method is the irrigation with the Yellow River water. The samples of Zone III are located around the lower reaches of Yellow River in Yinchuan Plain, and the isotope results are similar to those in Zone II. Most GW samples of Zone IV deviate from the LMWL to the right side and are distributed along a line with a 
smaller slope than the evaporation line of SW, which shows a strong evaporation effect. Some samples are scattered evenly on both sides of the evaporation line, with values around the mean value of the Yellow River water, which indicates that the recharge source of GW is the seepage of irrigation water from the Yellow River, and is strongly affected by evaporation during recharge. The values of some samples are distributed around the mean value of the spring water, reflecting the recharge relationship between GW and spring water. The lake samples are very scattered and obviously deviate from the LMWL, and most of them are located below the LMWL of Yinchuan and along the line with a slope of $5.23\left(\delta \mathrm{D}=5.23 \delta^{18} \mathrm{O}-20.42\right)$, which indicates that the lake water is affected by evaporation. Through systematic analysis of lake isotope samples of the lake, Qian et al. [40] suggests that the lake water comes from the Yellow River water or GW, or both. This partially proves that there is a local water flow system in Profile 1 flows to the lake. As shown in Figure 8B, samples of drainage ditches are very scattered and clearly deviate from the LMWL. The isotope samples of partial drainage ditches are in the middle of GW samples in the plain area, which indicates that the water in the partial drainage ditches comes from GW and is consistent with the presence of a local flow system around the drainage ditches in Profile 2. According to the field investigation, the water in the drainage ditches mainly comes from the water runoff into the drainage ditches after the paddy fields are irrigated, GW and domestic sewage $[36,38]$, thus leading to the above-described isotope characteristics of the water samples in drainage ditches.

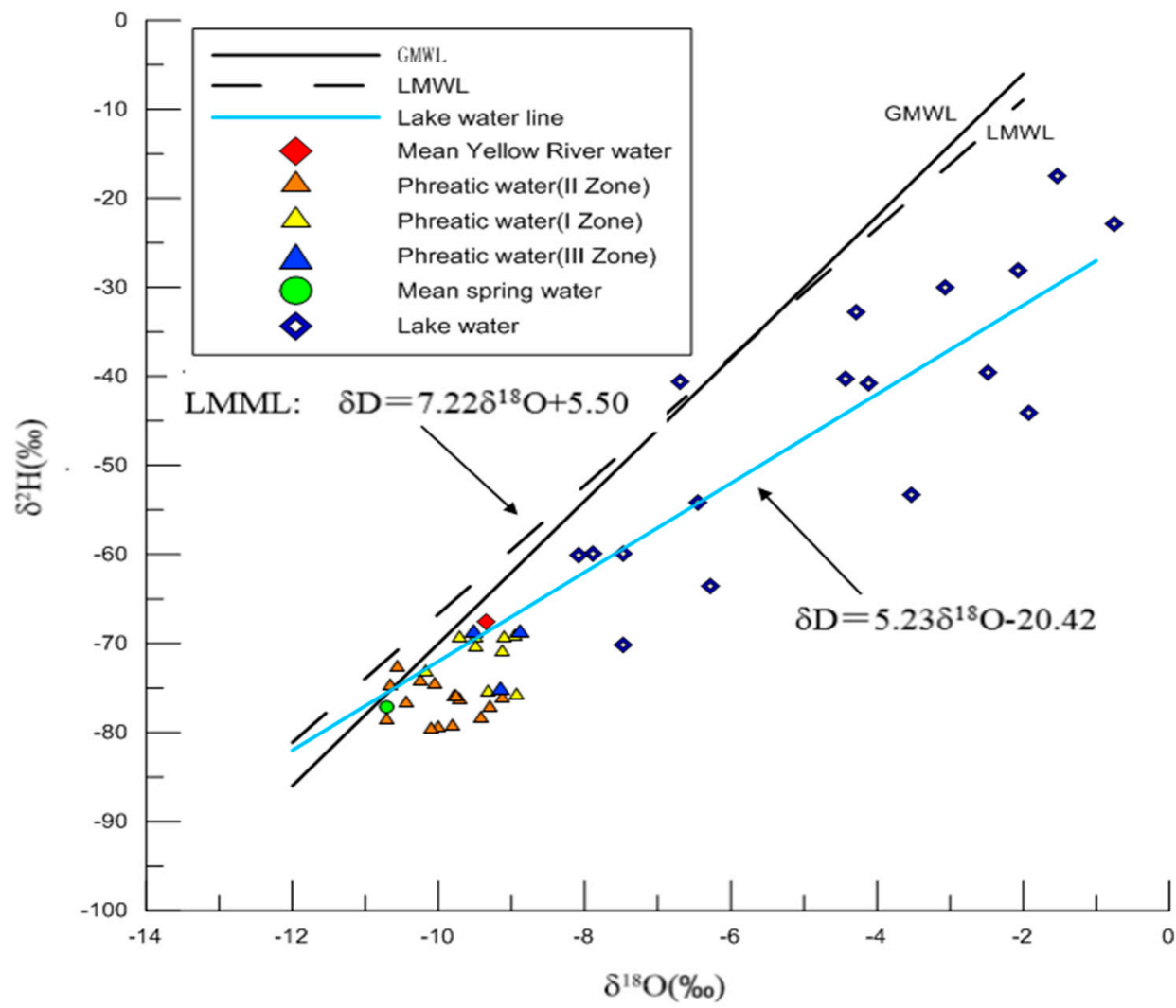

(a)

Figure 8. Cont. 


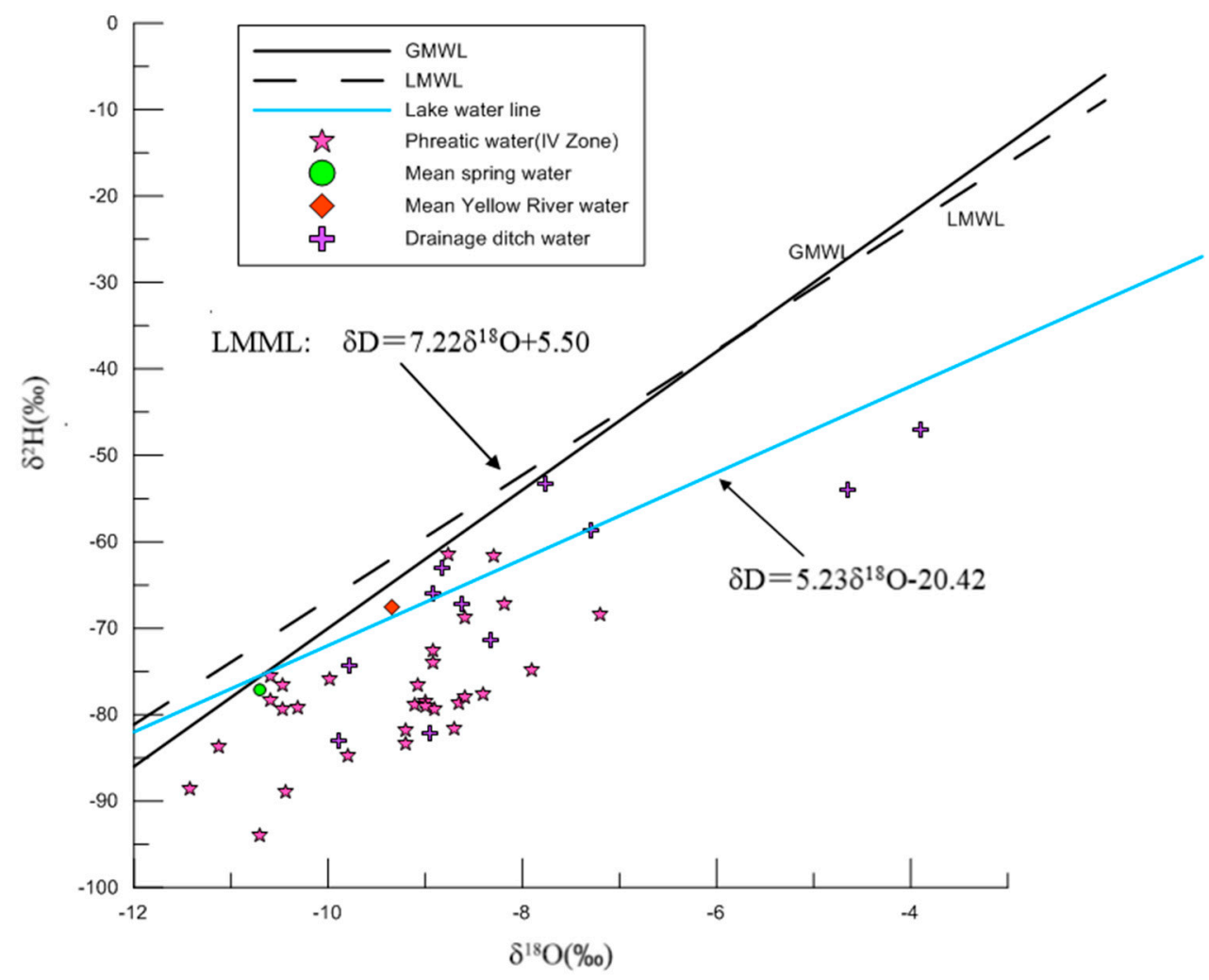

(b)

Figure 8. $\delta^{2} \mathrm{H}$ versus $\delta^{18} \mathrm{O}$ diagram of precipitation, surface water and groundwater of the Yinchuan Plain study area. (a) phreatic water (I,II,III Zone) and lake water. (b) phreatic water (IV Zone) and drainage ditch water.

\subsection{Geological Structure Controlling SW-GW Interaction}

Controlled by the Neotectonic Movement, Helan Mountain in the west of Yinchuan Plain has been continuously uplifted and steepened, with an elevation of 2000-3556 m, strongly cutting terrain. There is stable snow cover in winter, and rich precipitation in the rainy season. Rivers and flood channels originating in this area are mainly recharged by precipitation, glacial water, melt water and bedrock fissure water, and the water penetrates into the ground at the mountain mouth after short-term underground runoff, transforming into GW $[38,58]$. This area is a formation area of water resources in the watershed; with limited storage space and less GW resources, the water-rich sections are mostly concentrated in the fracture zone, fissure development section, mountain fault basin, river valley area and plain area, where relatively thick loose sediments are deposited. It is easy for flood infiltration, and most of the floods seep into the ground in the piedmont to form GW and finally enter the piedmont alluvial-pluvial fan. This alluvial-pluvial fan is a runoff transformation area of the watershed, with large storage space, abundant recharge sources and abundant storage and regulation resources, which is conducive to GW exploitation. Close to the piedmont alluvial-pluvial fan and affected by the geological structure, a set of fine-grained belts often deposits at the front of the alluvial sloping plain and the contact point of the alluvial plain [58], and the GW in the piedmont and low hills receives the meteoric water recharge and the surface flood recharge in the piedmont. The water partially seeps into the ground to form GW, moves from the high water head to the low water head, encounters the clay soil with lithology as fine particles, the GW runoff is hindered, and partially discharged to the surface in the form of spring. After partial GW enters the deep circulation, it is directly discharged to the terminal lake or the Yellow River, which constitutes the basic way of water resource transformation in arid and arid areas, i.e., SW-GW-SW. Regardless of the number of transformations, 
the watershed SW and GW are two different forms of the same recharge source. This kind of interaction is more common in arid and semi-arid areas of northwest China, such as southern Qaidam Basin in Qinghai [59], Junggar Basin in Xinjiang [4], Heihe River Basin [60], and Golmud River Basin [61].

The Yellow River flows from Qingtong Gorge to Yinchuan Plain. Due to the high water level in the upper reaches, a typical piedmont alluvial-pluvial fan is formed at the Yellow River water existence of the mountain mouth, and its aquifer is composed of gravel, with a loose structure, high porosity and permeability. In the alluvial-pluvial fan, the Yellow River water mainly recharges the GW. From the front edge of the alluvial-pluvial fan to the overflow zone, coarse particles are directly exposed on the ground surface or are covered only by a thin soil layer, which is very beneficial to absorb the SW from the mountain confluence. As the terrain becomes flatter, the particles become thinner, the water permeability becomes worse, the underground runoff is blocked, the water level is close to the surface because the GW is blocked and a lake or a marsh is formed. On the fine soil plain below the overflow zone, the terrain is flat, and the lithology is dominated by powder fine sand and clay, the relationship between the Yellow River and the GW becomes complicated, the Yellow River recharges the GW in the high-water period and the GW recharges the Yellow River in the low-water period. The Yellow River water and GW are mutually transformed one to three times to form a multi-stage nested flow system, in the mode of river water- GW-river water, forming another way of interaction of SW and GW in the basin.

Under the two common interaction modes of SW and GW, there is a basic mode that geological and geomorphological conditions control the formation and distribution of GW, and geological structures control the interaction of SW and GW flow systems. GW is driven by gravity, SW and GW are mutually transformed for one to four times from the recharge area to the runoff area and then to the discharge area. During GW flowing, the GW flow is affected by the heterogeneity and anisotropy of aquifer and forms a multi-stage nested flow system: local flow system, intermediate flow system and regional flow system [62]. There are great differences in its runoff intensity, GW renewal rate and water chemical composition $[63,64]$.

\subsection{The Impact of Human Activity}

In the alluvial-proluvial plain area of Yinchuan Plain, during spring irrigation and winter irrigation each year, a plurality of local flow systems formed by vertical seepage recharge are formed in the plain area, and the GW recharge sources are mainly the leakage of the Yellow River diversion canals and infiltration of irrigation. This form of recharge indirectly alters the movement of SW and GW. Irrigation seepage and canal leakage recharge account for $79.39 \%$ of total GW recharge sources [37,38]. In addition, the violent surface evaporation and irrational irrigation of agriculture in the plain area result in high soil salinization and nitrate content in some areas $[35,41,65]$. The construction of the Qingtongxia Reservoir and its dam in the upper reaches of the plain has changed the natural process and rules of the hydrological change of the original river, resulting in the decrease of the water level of the river and changes of the recharge relationship between the river and the surrounding GW. The regular sand discharge of the dam easily causes sediment deposition in the Yellow River streambed in the plain, reduces the amount of exchange between the river water and GW, and this in turn poses a threat to river and downstream ecosystems [66-68]. With the development of the city, the overexploitation of GW in local areas has resulted in varying degrees of regional GW drawdown funnels [41,69]. There were many lake wetlands in the history of Yinchuan Plain, and the lakes and marshes in the plain were affected by many natural factors such as land subsidence, sediment deposition, Yellow River flooding and climate drying during the geological period and human history. Since the development of the Yellow River Irrigation Area in the Han Dynasty, the changes of the lakes and marshes have been closely linked by the human development activities of the irrigation area, and the natural factors are relatively secondary $[40,70]$.

In arid and semi-arid basins with limited water resources, human activities are closely related to the development and utilization of water resources, such as the construction of reservoirs, the diversion 
of river channels, the networking of river channels and canals, the transfer of water across basins, and the exploitation of GW, interfering with the SW and GW circulation to the native state, and changing the recharge-discharge relationship between rivers and groundwater aquifers [71,72], causing a decline in the exchange of SW and GW in some basins, complicating the evolution of the relationship between SW and GW, and producing a series of ecological and environmental problems [73,74].

\subsection{SW-GW Interaction Process in Yinchuan Plain}

The SW-GW interaction in Yinchuan Plain can be classified into three typical types by comparing and analyzing the hydrogeological structure and GW flow system of the three typical profiles in the study area: (1) SW-GW interaction in piedmont alluvial-pluvial fan. In general, the SW-GW interaction process is as follows: The GW in the mountain area is recharged by the meteoric water and ice-snow melt water, and part of the SW is transformed into GW by infiltration from the surface runoff to the piedmont alluvial-pluvial fan, some GW is affected by lithology to the edge of the alluvial fan and fine soil plain to overflow into spring, and some GW is discharged to the downstream tail-end lake or terminal river with deep circulation. During the whole circulation process, SW and GW transform 3-5 times. (2) SW-GW interaction under impact of human activities. In this type, SW and GW are transformed 2-3 times, and the Yellow River water is introduced to the irrigation area through the Yellow River diversion canal, the GW is recharged through infiltration of irrigation and the Yellow River diversion canals leakage, and is discharged through evaporation and drainage ditches. Some of the GW is also drained to the Yellow River through drainage ditches or underground runoff. (3) River water-GW interaction. In this type, the GW has a close hydraulic connection with the Yellow River water, and the Yellow River undergoes multiple interactions with GW in the course of its flow. In the upstream alluvial fan of the Yellow River, the main mode is that the Yellow River becomes disconnected with GW and recharges the GW. The Yellow River and GW in other regions have a unified infiltration curve under natural conditions. Affected by the seasonal variation, there is a big difference in the water level of the Yellow River, which makes the Yellow River recharge GW in the high-water period, while the GW recharge the Yellow River in the low-water and plain-water periods.

\subsection{Exploration of GW Resources Exploitation}

SW, GW and the ecological environment form a community. The dynamic process of GW interaction drives the transmission and circulation of materials and energy, and strengthens the coupling among GW, meteoric water (and evaporation), SW and the ecological environment. It is necessary to figure out the transformation principles of SW and GW with the theory of systematic hydrology cycle, and deal with the problems of regional lake and wetland protection, water resource exploration and agricultural irrigation. According to the above analysis on three typical SW-GW circulation modes and evolutions in Yinchuan Plain, combined with the current status of human activities in the region, the following recommendations are proposed for optimized allocation of GW resources:

(1) The Helan Mountain Floodplain is the main recharge area of the regional GW flow system. Because there is no perennial river in Helan Mountain, the rainfall is scarce, the recharge is limited, and the GW renewability is poor, so it is not suitable for large-scale development of GW.

(2) In the alluvial fan plain area of the upper reaches of the Yellow River, the GW in this area is mainly recharged by the Yellow River, and the sand gravel layer below the surface is conducive for the seepage of irrigation water. The GW renewability is strong and the water quality is excellent, which can be used as a water source for Yinchuan City.

(3) Current mode, i.e., relying merely on Yellow River water for irrigation, in main irrigation areas in the Yinchuan Plain should be changed. The combination of canal irrigation and well irrigation should be used to improve the drainage ditches, limit the amount of SW irrigation, and rationally develop and utilize shallow GW. This will not only prevent soil from salinization, and improve 
soil quality, but also reduce the inefficient evaporation of shallow GW, advance the utilization efficiency of water resources, and alleviate the contradiction between supply and demand of water resources.

(4) There are many lake wetlands in Yinchuan Plain. In order to protect the lake wetlands, we must focus on the hydrological cycle, sustain the source of lakes and pay more attention to the impact of the SW-GW interaction.

\section{Conclusions}

In this study, three typical profiles are selected in Yinchuan Plain. The numerical simulation combined with geological analysis, water chemistry and isotope analysis methods are used to comprehensively analyze the typical modes of SW-GW interaction in Yinchuan Plain, and the intrinsic complexity is generalized. The main conclusions are as follows:

(1) In arid and semi-arid areas, there are frequent mutual interactions between SW and GW. The geological structure controls the basic mode of SW-GW interaction. In the mountain fault basin, river valley areas and plain areas, thick loose sediments are accumulated, forming the main GW recharge area. The piedmont sag and alluvial-proluvial plain is the watershed-runoff transformation area where precipitation is rare and evaporation is intense. The downstream lake wetlands are the consumption areas of water resources.

(2) Through the construction of reservoirs, water diversion irrigation, groundwater development and other closely related activities, human activities interfere with the SW and GW circulation to the native state, change the recharge-discharge relationship between SW and GW aquifers, and cause a decline in the exchange of SW and GW. It further homogenizes the spatial distribution of GW recharge and discharge conditions, and extends the affected area, which causes variation of the dynamic field and hydro-chemical field of the GW system, even causes the great change of GW quality and induces certain negative effects on geological-ecological environments.

(3) From mountainous areas to plains, the SW-GW interaction in different geological and geomorphological units is an important feature of water resources in arid and semi-arid areas. The GW flow system controls the evolution of SW modes and the dynamics of phreatic level. The GW maintains the wetland area such as the overflow zone and the tail-end lake. To maintain the area of the lake and wetland in the Yinchuan Plain, the development of GW resources in the recharge area must be controlled regarding the regional hydrological cycle.

(4) The topography controls the material migration in the water and the lithology of the strata provides the chemical composition in the water. In arid and semi-arid areas, arid climate and strong evaporation determine the material accumulation, human activities lead to the accumulation of a certain degree of change and water chemistry has an indicative role in the circulation of GW, which can effectively reveal the SW-GW interaction. From the piedmont to the plain in Yinchuan Plain, and during the mutual interaction of $\mathrm{SW}$ and $\mathrm{GW}$, their hydro-chemical types are $\mathrm{HCO}_{3}$, $\mathrm{HCO}_{3} \bullet \mathrm{SO}_{4}\left(\mathrm{SO}_{4} \bullet \mathrm{HCO}_{3}\right), \mathrm{HCO}_{3} \bullet \mathrm{SO}_{4} \bullet \mathrm{CI}$ and $\mathrm{HCO}_{3} \bullet \mathrm{CI}\left(\mathrm{CI} \bullet \mathrm{HCO}_{3}\right.$ or $\left.\mathrm{CI}_{4} \bullet \mathrm{SO}_{4}\right)$, and cations are transformed from $\mathrm{Ca}(\mathrm{Ca} \bullet \mathrm{Na}, \mathrm{Ca} \bullet \mathrm{Mg})$ to $\mathrm{Na} \bullet \mathrm{Mg}(\mathrm{Na})$. Along the Yellow River, the evolution of GW chemistry is similar, from $\mathrm{HCO}_{3} \bullet \mathrm{SO}_{4}$ to $\mathrm{HCO}_{3} \bullet \mathrm{Cl} \bullet \mathrm{Na} \bullet \mathrm{Mg}$ and $\mathrm{SO}_{4} \bullet \mathrm{Cl} \bullet \mathrm{Na} \bullet \mathrm{Mg}$, and then $\mathrm{Cl} \bullet \mathrm{SO}_{4}$ in the lower reaches, with obvious horizontal zoning which is consistent with the topographic relief, conforms to the law of continental salt accumulation and also reflects the SW-GW interaction.

This study is of great significance to know about the SW-GW interaction relationship in Yinchuan Plain, realize the joint development of SW and GW, optimize the allocation of water resources and guide the utilization rate of water resources and ecological environment protection along the Yellow River Economic Belt. 
Author Contributions: W.W. and Z.C. designed the idea and structure of the article, M.Z. and Z.M. analyzed the data, Z.C. and C.L. carried out numerical simulation, Y.L. drew the graph, Z.C., M.Z. and Z.M. wrote the paper. All authors have read and agreed to the published version of the manuscript.

Funding: This research was funded by National Natural Science Foundation of China (No. 41672241), the Geological Survey Project of China Geological Survey (No. DD20190433), and Project of Ningxia Finance Department (No. 6400201901273).

Conflicts of Interest: The authors declare no conflict of interest.

\section{References}

1. Sophocleous, M. Interactions between groundwater and surface water: The state of the science. Hydrogeol. J. 2002, 10, 52-67. [CrossRef]

2. Lambs, L. Interactions between groundwater and surface water at river banks and the confluence of rivers. J. Hydrol. 2004, 288, 312-326. [CrossRef]

3. Kalbus, E.; Reinstorf, F.; Schirmer, M. Measuring methods for groundwater? surface water interactions: A review. Hydrol. Earth Syst. Sci. 2006, 10, 873-887. [CrossRef]

4. Wang, W.; Wang, Z.; Hou, R.; Guan, L.; Dang, Y.; Zhang, Z.; Wang, H.; Duan, L.; Wang, Z. Modes, hydrodynamic processes and ecological impacts exerted by river-groundwater transformation in Junggar Basin, China. Hydrogeol. J. 2018, 26, 1547-1557. [CrossRef]

5. Kalbus, E.; Schmidt, C.; Molson, J.W.; Reinstorf, F.; Schirmer, M. Influence of aquifer and streambed heterogeneity on the distribution of groundwater discharge. Hydrol. Earth Syst. Sci. 2009, 13, 69-77. [CrossRef]

6. Winter, T.C. Relation of streams, lakes, and wetlands to groundwater flow systems. Hydrogeol. J. 1999, 7, 28-45. [CrossRef]

7. Trásy, B.; Kovács, J.; Hatvani, I.; Havril, T.; Nemeth, T.; Scharek, P.; Szabo, C. Assessment of the interaction between surface- and groundwater after the diversion of the inner delta of the River Danube (Hungary) using multivariate statistics. Anthropocene 2018, 22, 51-65. [CrossRef]

8. Wu, X.; Zheng, Y.; Wu, B.; Tian, Y.; Han, F.; Zheng, C. Optimizing conjunctive use of surface water and groundwater for irrigation to address human-nature water conflicts: A surrogate modeling approach. Agric. Water Manag. 2016, 163, 380-392. [CrossRef]

9. Liu, F.; Song, X.; Yang, L.; Han, D.; Zhang, Y.; Ma, Y.; Bu, H. The role of anthropogenic and natural factors in shaping the geochemical evolution of groundwater in the Subei Lake basin, Ordos energy base, Northwestern China. Sci. Total. Environ. 2015, 538, 327-340. [CrossRef]

10. Wang, S.; Tang, C.; Song, X.; Wang, Q.; Zhang, Y.; Yuan, R. The impacts of a linear wastewater reservoir on groundwater recharge and geochemical evolution in a semi-arid area of the Lake Baiyangdian watershed, North China Plain. Sci. Total. Environ. 2014, 482, 325-335. [CrossRef]

11. Saha, G.C.; Li, J.; Thring, R.W.; Hirshfield, F.; Paul, S. Temporal dynamics of groundwater-surface water interaction under the effects of climate change: A case study in the Kiskatinaw River Watershed, Canada. J. Hydrol. 2017, 551, 440-452. [CrossRef]

12. Wang, W.; Zhang, Z.; Duan, L.; Wang, Z.; Zhao, Y.; Zhang, Q.; Dai, M.; Liu, H.; Zheng, X.; Sun, Y. Response of the groundwater system in the Guanzhong Basin (central China) to climate change and human activities. Hydrogeol. J. 2018, 26, 1429-1441. [CrossRef]

13. Garamhegyi, T.; Kovács, J.; Pongrácz, R.; Tanos, P.; Hatvani, I.G. Investigation of the climate-driven periodicity of shallow groundwater level fluctuations in a Central-Eastern European agricultural region. Hydrogeol. J. 2017, 26, 677-688. [CrossRef]

14. Lee, D.R. A device for measuring seepage flux in lakes and estuaries1. Limnol. Oceanogr. 1977, $22,140-147$. [CrossRef]

15. Lee, D.R.; Cherry, J.A. A Field Exercise on Groundwater Flow Using Seepage Meters and Mini-piezometers. J. Geol. Educ. 1979, 27, 6-10. [CrossRef]

16. Woessner, W.W.; Sullivan, K.E. Results of Seepage Meter and Mini-Piezometer Study, Lake Mead, Nevada. Ground Water 1984, 22, 561-568. [CrossRef]

17. Isiorho, S.A.; Meyer, J.H. The Effects of Bag Type and Meter Size on Seepage Meter Measurements. Ground Water 1999, 37, 411-413. [CrossRef] 
18. Chen, Z.; Chen, J.; Fei, Y.; Zhang, Z.; Zhang, C. Estimation of groundwater renewal rate by tritium in the piedmont plain of the Taihang Mountains. Nucl. Tech. 2006, 29, 426-431.

19. Xu, W.; Xiaosi, S.; Dai, Z.; Yang, F.; Zhu, P.; Huang, Y. Multi-tracer investigation of river and groundwater interactions: A case study in Nalenggele River basin, northwest China. Hydrogeol. J. 2017, 25, 2015-2029. [CrossRef]

20. Negrel, P.; Petelet-Giraud, E.; Barbier, J.; Gautier, E. Surface water-groundwater interactions in an alluvial plain: Chemical and isotopic systematics. J. Hydrol. 2003, 277, 248-267. [CrossRef]

21. Hakam, O.K.; Choukri, A.; Moutia, Z.; Chouak, A.; Cherkaoui, R.; Reyss, J.-L.; Lferde, M. Uranium and radium in groundwater and surface water samples in Morocco. Radiat. Phys. Chem. 2001, 61, 653-654. [CrossRef]

22. Cook, P.G.; Favreau, G.; Dighton, J.; Tickell, S. Determining natural groundwater influx to a tropical river using radon, chlorofluorocarbons and ionic environmental tracers. J. Hydrol. 2003, 277, 74-88. [CrossRef]

23. Unland, N.P.; Cartwright, I.; Andersen, M.S.; Rau, G.C.; Reed, J.; Gilfedder, B.S.; Atkinson, A.P.; Hofmann, H. Investigating the spatio-temporal variability in groundwater and surface water interactions: A multi-technique approach. Hydrol. Earth Syst. Sci. 2013, 17, 3437-3453. [CrossRef]

24. Oyarzún, R.; Barrera, F.; Salazar, P.; Maturana, H.; Oyarzún, J.; Aguirre, E.; Alvarez, P.; Jourde, H.; Kretschmer, N. Multi-method assessment of connectivity between surface water and shallow groundwater: The case of Limarí River basin, north-central Chile. Hydrogeol. J. 2014, 22, 1857-1873. [CrossRef]

25. Wang, P.; Yu, J.; Zhang, Y.; Liu, C. Groundwater recharge and hydrogeochemical evolution in the Ejina Basin, northwest China. J. Hydrol. 2013, 476, 72-86. [CrossRef]

26. Martinez, J.L.; Raiber, M.; Cox, M. Assessment of groundwater-surface water interaction using long-term hydrochemical data and isotope hydrology: Headwaters of the Condamine River, Southeast Queensland, Australia. Sci. Total Environ. 2015, 536, 499-516. [CrossRef]

27. Boano, F.; Revelli, R.; Ridolfi, L. Effect of streamflow stochasticity on bedform-driven hyporheic exchange. Adv. Water Resour. 2010, 33, 1367-1374. [CrossRef]

28. Frei, S.; Fleckenstein, J.H.; Kollet, S.; Maxwell, R. Patterns and dynamics of river-aquifer exchange with variably-saturated flow using a fully-coupled model. J. Hydrol. 2009, 375, 383-393. [CrossRef]

29. Jin, G.; Tang, H.W.; Gibbes, B.; Li, L.; Barry, D.A. Transport of nonsorbing solutes in a streambed with periodic bedforms. Adv. Water Resour. 2010, 33, 1402-1416. [CrossRef]

30. Guay, C.; Nastev, M.; Paniconi, C.; Sulis, M. Comparison of two modeling approaches for groundwater-surface water interactions. Hydrol. Process. 2012, 27, 2258-2270. [CrossRef]

31. Jones, J.P.; Sudicky, E.A.; McLaren, R.G. Application of a fully-integrated surface-subsurface flow model at the watershed-scale: A case study. Water Resour. Res. 2008, 44, 893-897. [CrossRef]

32. Sterte, E.J.; Johansson, E.; Sjöberg, Y.; Karlsen, R.H.; Laudon, H. Groundwater-surface water interactions across scales in a boreal landscape investigated using a numerical modelling approach. J. Hydrol. 2018, 560, 184-201. [CrossRef]

33. Ala-Aho, P.; Rossi, P.M.; Isokangas, E.; Kløve, B. Fully integrated surface-subsurface flow modelling of groundwater-lake interaction in an esker aquifer: Model verification with stable isotopes and airborne thermal imaging. J. Hydrol. 2015, 522, 391-406. [CrossRef]

34. Menció, A.; Galán, M.; Boix, D.; Mas-Pla, J. Analysis of stream-aquifer relationships: A comparison between mass balance and Darcy's law approaches. J. Hydrol. 2014, 517, 157-172. [CrossRef]

35. Li, P.; Qian, H.; Wu, J. Conjunctive use of groundwater and surface water to reduce soil salinization in the Yinchuan Plain, North-West China. Int. J. Water Resour. Dev. 2018, 34, 337-353. [CrossRef]

36. Qian, H.; Li, P.; Wu, J.; Zhou, Y. Isotopic characteristics of precipitation, surface and ground waters in the Yinchuan plain, Northwest China. Environ. Earth Sci. 2012, 70, 57-70. [CrossRef]

37. Jing, X.-Y.; Yang, H.; Cao, Y.; Wang, W. Identification of indicators of groundwater quality formation process using a zoning model. J. Hydrol. 2014, 514, 30-40. [CrossRef]

38. Geological Survey Institute of Ningxia Hui Autonomous Region. The Report on the Hydrogeological Environmental Geological Survey of the Yellow River Economic Zone in Ningxia; Technical Report 1212011220973; Geological Survey Institute of Ningxia Hui Autonomous Region: Yinchuan, China, 2016.

39. Qian, H.; Li, P.Y. Hydrochemical characteristics of groundwater in Yinchuan plain and their control factors. Asian J. Chem. 2011, 23, 2927. 
40. Qian, H.; Wu, J.; Zhou, Y.; Li, P. Stable oxygen and hydrogen isotopes as indicators of lake water recharge and evaporation in the lakes of the Yinchuan Plain. Hydrol. Process. 2013, 28, 3554-3562. [CrossRef]

41. Li, Z.; Yang, Q.; Yang, Y.; Ma, H.; Wang, H.; Luo, J.; Bian, J.; Martin, J.D.; Li, S. Isotopic and geochemical interpretation of groundwater under the influences of anthropogenic activities. J. Hydrol. 2019, 576, 685-697. [CrossRef]

42. Guo, Q.; Yang, Y.; Han, Y.; Li, J.; Wang, X. Assessment of surface-groundwater interactions using hydrochemical and isotopic techniques in a coalmine watershed, NW China. Environ. Earth Sci. 2019, 78, 91. [CrossRef]

43. Fan, C.-C.; Chen, Y.-W. The effect of root architecture on the shearing resistance of root-permeated soils. Ecol. Eng. 2010, 36, 813-826. [CrossRef]

44. Fan, H.X. Open a new era of groundwater monitoring-focus on the construction of national groundwater monitoring project. Hydrogeol. Eng. Geol. 2015, 2, 161-162. (In Chinese)

45. Cheng, Z.S.; Li, Y.; Chen, Z.Y.; Cui, W.X.; Xue, Z.Q. Distribution characteristics and age of Tritium in phreatic aquifers in Yinchuan plain. Environ. Earth Sci. 2019, 33, 141-147. (In Chinese)

46. Chen, Z.; Wei, W.; Liu, J.; Wang, Y.; Chen, J. Identifying the recharge sources and age of groundwater in the Songnen Plain (Northeast China) using environmental isotopes. Hydrogeol. J. 2010, 19, 163-176. [CrossRef]

47. Härdle, W.K.; Simar, L. Applied Multivariate Statistical Analysis; Springer Science and Business Media LLC: Berlin, Germany; Louvainla Neuve, Belgium, 2012.

48. Doney, S.C.; Glover, D.M.; Jenkins, W.J. A model function of the global bomb tritium distribution in precipitation, 1960-1986. J. Geophys. Res. Oceans 1992, 97, 5481-5492. [CrossRef]

49. Ba, Q.; Xu, Y. Input function and simulated distributions of tritium in the North Pacific. Sci. China Earth Sci. 2010, 53, 441-453. [CrossRef]

50. Liu, J.; Chen, Z.; Wei, W.; Zhang, Y.; Li, Z.; Liu, F.; Guo, H. Using chlorofluorocarbons (CFCs) and tritium $\left({ }^{3} \mathrm{H}\right)$ to estimate groundwater age and flow velocity in Hohhot Basin, China. Hydrol. Process. 2013, 28, 1372-1382. [CrossRef]

51. Maloszewski, P.; Zuber, A. Lumped Parameter Models for the Interpretation of Environmental Tracer Data, Manual on Mathematical Models in Isotope Hydrogeology, TECDOC-910; International Atomic Energy Agency: Vienna, Austria, 1996; pp. 9-58. Available online: https://www.mendeley.com/catalogue/61bdaeb9-4614-34f2-a359570efc442d39/ (accessed on 21 September 2020).

52. Salle, C.L.G.L.; Marlin, C.; LeDuc, C.; Taupin, J.; Massault, M.; Favreau, G. Renewal rate estimation of groundwater based on radioactive tracers $\left({ }^{3} \mathrm{H},{ }^{14} \mathrm{C}\right)$ in an unconfined aquifer in a semi-arid area, Iullemeden Basin, Niger. J. Hydrol. 2001, 254, 145-156. [CrossRef]

53. Chen, Z.; Nie, Z.; Zhang, G.; Wan, L.; Shen, J. Environmental isotopic study on the recharge and residence time of groundwater in the Heihe River Basin, northwestern China. Hydrogeol. J. 2006, 14, 1635-1651. [CrossRef]

54. Yang, Z.; Li, H.X.; Wu, X.H.; Liu, H.M. Estimating of the update speed of groundwater in YinChuan plain by using the radioactive element ${ }^{3} \mathrm{H}$. Ningxia Eng. Technol. 2007, 6, 84-87. (In Chinese)

55. Wang, F. Study on Dynamic Characteristics of Groundwater and Age Distribution of Groundwater in Yinchuan Plain. Master's Thesis, China University of Geosciences (Beijing), Beijing, China, 2017. (In Chinese).

56. Islam, B.; Firoz, A.B.M.; Foglia, L.; Marandi, A.; Khan, A.R.; Schüth, C.; Ribbe, L. A regional groundwater-flow model for sustainable groundwater-resource management in the south Asian megacity of Dhaka, Bangladesh. Hydrogeol. J. 2017, 25, 617-637. [CrossRef]

57. Gu, X.; Shao, J.; Cui, Y.; Hao, Q. Calibration of Two-Dimensional Variably Saturated Numerical Model for Groundwater Flow in Arid Inland Basin, China. Curr. Sci. 2017, 113, 403-412. [CrossRef]

58. Wu, X.H.; Qian, H.; Yu, D.M. Investigation and Assessment of Rational Allocation of Groundwater Resources in the Yinchuan Plain; Geology Publishing House: Beijing, China, 2008.

59. Xiao, Y.; Shao, J.; Frape, S.K.; Cui, Y.; Dang, X.; Wang, S.; Ji, Y. Groundwater origin, flow regime and geochemical evolution in arid endorheic watersheds: A case study from the Qaidam Basin, northwestern China. Hydrol. Earth Syst. Sci. 2018, 22, 4381-4400. [CrossRef]

60. Yao, Y.; Zheng, C.; Tian, Y.; Liu, J.; Zheng, Y. Numerical modeling of regional groundwater flow in the Heihe River Basin, China: Advances and new insights. Sci. China Earth Sci. 2014, 58, 3-15. [CrossRef]

61. Wang, Y. Geochemistry Evolution and Water Cycle Patterns of Groundwater in Golmud River Basin. Master's Thesis, Chang'an University, Xi'an, China, 2014. (In Chinese) 
62. Tóth, J. A theoretical analysis of groundwater flow in small drainage basins. J. Geophys. Res. 1963, 68, 4795-4812. [CrossRef]

63. Liang, X.; Quan, D.; Jin, M.; Liu, Y.; Zhang, R. Numerical simulation of groundwater flow patterns using flux as upper boundary. Hydrol. Process. 2012, 27, 3475-3483. [CrossRef]

64. Jiang, X.-W.; Wan, L.; Wang, X.-S.; Ge, S.; Liu, J. Effect of exponential decay in hydraulic conductivity with depth on regional groundwater flow. Geophys. Res. Lett. 2009, 36. [CrossRef]

65. Jin, X.M.; Hu, G.C.; Shi, X.J. Relationship between soil salinization and the vegetation growing, groundwater depth in the Yinchuan. Geoscience 2009, 1, 25-29. (In Chinese)

66. Richter, B.; Baumgartner, J.; Wigington, R.; Braun, D. How much water does a river need? Freshw. Biol. 1997, 37, 231-249. [CrossRef]

67. Yang, T.; Zhang, Q.; Chen, Y.D.; Tao, X.; Xu, C.-Y.; Chen, X. A spatial assessment of hydrologic alteration caused by dam construction in the middle and lower Yellow River, China. Hydrol. Process. 2008, 22, 3829-3843. [CrossRef]

68. Sun, Z.Y.; Wang, Y.J.; Zheng, Y.S.; Liu, Y.H. Influence of desilting of Qingtongxia Reservoir to the channel Scour and fill of the lower reaches. Yellow River 2014, 36, 9-11. (In Chinese)

69. Zhang, Q.; Zhang, L. Main Water Environmental Problem and Its Countermeasures in Yinchuan Plain. J. Earth Sci. Environ. 2010, 4, 66-71. (In Chinese)

70. Wang, Y.M. The historical changes and future utilization of lakes in Yinchuan plain. Arid Area Res. Environ. 1992, 6, 47-57. (In Chinese)

71. Hussein, M.; Schwartz, F.W. Modeling of flow and contaminant transport in coupled stream-aquifer systems. J. Contam. Hydrol. 2003, 65, 41-64. [CrossRef]

72. Fleckenstein, J.H.; Anderson, M.; Fogg, G.; Mount, J. Managing Surface Water-Groundwater to Restore Fall Flows in the Cosumnes River. J. Water Resour. Plan. Manag. 2004, 130, 301-310. [CrossRef]

73. Yang, Z.; Zhou, Y.; Wenninger, J.; Uhlenbrook, S.; Wang, X.; Wan, L. Groundwater and surface-water interactions and impacts of human activities in the Hailiutu catchment, northwest China. Hydrogeol. J. 2017, 25, 1341-1355. [CrossRef]

74. Webb, R.H.; Leake, S.A. Ground-water surface-water interactions and long-term change in riverine riparian vegetation in the southwestern United States. J. Hydrol. 2006, 320, 302-323. [CrossRef]

(C) 2020 by the authors. Licensee MDPI, Basel, Switzerland. This article is an open access article distributed under the terms and conditions of the Creative Commons Attribution (CC BY) license (http://creativecommons.org/licenses/by/4.0/). 